\title{
Decadal declines in bird abundance and diversity in urban riparian zones
}

Mélanie J. BANVILLE ${ }^{\text {a }}$, Heather L. BATEMAN ${ }^{\text {a, b }}$, Stevan R. EARL ${ }^{\text {a }}$, Paige S. WARREN ${ }^{\text {a, c }}$

${ }^{a}$ Central Arizona-Phoenix Long-Term Ecological Research, Julie Ann Wrigley Global Institute of Sustainability, Arizona State University, Tempe, AZ, USA (melanie.banville@asu.edu, stevan.earl@asu.edu)

${ }^{\mathrm{b}}$ College of Integrative Sciences and Arts, Arizona State University, Mesa, AZ, USA (heather.bateman@gmail.com)

${ }^{c}$ Department of Environmental Conservation, University of Massachusetts-Amherst, Amherst, MA, USA (pswarren@eco.umass.edu)

Corresponding Author:

Heather L. Bateman

Arizona State University

6073 S Backus Mall, MC 2780

Mesa, AZ 85212

Office: 480.727 .1131

heather.bateman@gmail.com and hbatema1@asu.edu 


\begin{abstract}
Urbanization is frequently cited as a major driver of species losses worldwide; however, most studies in urban areas use a space-for-time substitution approach to document effects of urbanization through time. Ultimately, understanding the effects of urbanization on biodiversity requires long-term datasets. We examined long-term changes in bird assemblages at 12 riparian sites in the greater Phoenix metropolitan area and nearby Sonoran Desert region, featuring a range of human modifications and levels of water flow. Riparian areas in arid cities represent a key habitat type that is sensitive to human modification and supports high levels of species diversity. We used long-term data to: (1) explore variation in bird communities as a function of water permanence and degree of human-modification; (2) identify which environmental variables best describe differences found across riparian site types; and (3) assess how riparian bird communities, abundance, and species richness have changed through time. Engineered riparian sites supported more broadly distributed generalists; whereas, natural riparian sites supported more specialists. Sites with perennial flows had more vegetation and water compared to ephemeral sites and engineered sites had more impervious surface compared to natural sites. In nearly all comparisons, bird species richness, diversity, and abundance declined across riparian types during the period of study, even for common species. Bird communities in natural settings have changed more than communities at engineered sites. Overall, the riparian bird community is shifting toward urban dwelling, resident species that are characteristic of riparian sites with less water and more impervious surface.
\end{abstract}




\section{Introduction}

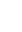

Worldwide, urban areas are expanding and are among the most rapidly changing landscapes. Urban areas modify wildlife habitat by replacing native vegetation cover with structures, roads, and other impervious surfaces (Czech, Krausman, \& Devers, 2000) among many other effects (Pickett, Cadenasso, Grove, Boone, Groffman, et al., 2011). Bird species density (the number of species/area) in cities is reduced relative to surrounding regions, and appears to be highly sensitive to changes in land cover (Aronson, La Sorte, Nilon, Katti, Goddard, et al., 2014). However, most urbanization studies use a space-for-time substitution approach to document effects of urbanization through time (Pickett et al., 2011). Understanding effects of urbanization on biodiversity requires long-term datasets, which document temporal changes in species composition and species gains or losses (Magurran, Baillie, Buckland, Dick, Elston, et al., 2010; Strohbach, Hrycyna, \& Warren, 2014).

Although cities are designed primarily for the benefit of humans, many species of wildlife persist and thrive in urban environments (Aronson et al., 2014; Marzluff, 2001; McKinney, 2002; Pickett et al., 2011). Many large cities occur along waterways, and can alter stream hydrology and watershed infiltration because of impervious surfaces (Paul \& Meyer, 2001). However, a more basic challenge in arid ecosystems is to provide sufficient water to maintain riparian ecosystems. In arid cities, perennial water from novel urban sources, such as storm drains, can support riparian areas with diverse plant and bird communities (Bateman, Stromberg, Banville, Makings, Scott, et al., 2015). Compared to other ecosystems, riparian areas support some of the highest bird diversities (Knopf \& Samson, 1994), but can also be habitats that are highly sensitive to modification (Naiman, Decamps, \& Pollock, 1993). Therefore, there 
23 is a growing need to identify sustainable mechanisms to restore and maintain urban riparian

24 ecosystems and the services, such as habitat, they provide (Bernhardt \& Palmer, 2007).

During the last century, the greater Phoenix metropolitan area in central Arizona has had 26 one of the fastest growing populations in the United States (Hobbs \& Stoops, 2002). In this

27 region, a system of channels and canals transport water from reservoirs on the Verde, Salt, and

28 Colorado Rivers (Gober, Wentz, Lant, Tschudi, \& Kirkwood, 2011) to support a large urban 29 population of 4 million in Maricopa County (U.S. Census Bureau, 2015). Employing datasets available from the Central Arizona-Phoenix Long-Term Ecological Research program

31 (https://caplter.asu.edu), we examined the effects of urbanization on riparian habitats and bird

32 communities in Phoenix and the surrounding Sonoran Desert region. The aims of our study were 33 to: (1) explore variation in bird species richness, abundance, and community composition as a 34 function of water permanence and degree of human-modification; (2) identify which 35 environmental variables measured at different scales (site- and landscape-level) best describe 36 differences in habitat characteristics found across riparian site types; and (3) examine the 37 temporal patterns of avian abundance, species richness, and diversity across riparian site types.

\section{Methods}

\subsection{Study area}

Our research was conducted within the study area of the Central Arizona-Phoenix Long-

41 Term Ecological Research program (hereafter CAP LTER), which encompasses the greater

42 Phoenix metropolitan area and surrounding Sonoran Desert (hereafter Phoenix; Fig. 1). CAP

43 LTER established two to four study sites in each of four riparian habitat types: (1) ephemeral44 engineered $(n=4) ;(2)$ ephemeral-natural $(n=2) ;(3)$ perennial-engineered $(n=3)$; and (4) 
45 perennial-natural $(n=3)$. CAP LTER defined types as ephemeral versus perennial based on the

46 permanence of water. Types were also classified as engineered or natural defined by the degree

47 of human-modification, which is more of a continuum rather than a dichotomy. Specifically, the

48 ephemeral-engineered sites included a 200-m square retention basin surrounded by

49 neighborhoods, two unlined earthen flood control channels surrounded by neighborhoods and

50 golf courses, and one artificial water catchment surrounded by desert. The ephemeral-natural

51 sites were along intermittent rivers surrounded by desert and some low density residential areas.

52 The perennial-engineered sites included a landscaped riparian preserve, a constructed wetland,

53 and a water retention area along the Salt River. These sites were surrounded by urban or

54 agricultural areas. The perennial-natural sites were located along perennial river reaches and

55 were surrounded by desert. Sites ranged between 295 and $683 \mathrm{~m}$ in elevation.

Following Bibby, Burgess, Hill, and Mustoe (2000), CAP LTER used point count surveys with a 40-m fixed-radius where a trained observer recorded all birds seen and heard. At

59 each point, the observer remained quiet for five minutes, then recorded birds for 15 minutes.

60 Observers identified species based on Sibley (2000), and classified species according to Pyle and

61 DeSante (2013). Birds detected beyond the 40-m truncation distance or that flew over the point

62 were not counted, except for wide-ranging and foraging species (i.e. waterfowl, shorebirds, birds

63 of prey, nighthawks, Greater Roadrunner, Geococcyx californianus; Belted Kingfisher,

64 Megaceryle alcyon; and Loggerhead Shrike, Lanius ludovicianus). Surveys were conducted

65 under similar environmental conditions and were completed within four hours of sunrise. From

662001 to 2013 (surveys were not conducted in 2003), three observers visited each point twice 
67 annually, once during winter (end of December to mid-February) and once during spring (end of 68 March to mid-May).

\subsection{Vegetation and environmental variables}

We collected eight site-level (within a 40-m radius around the point) and four landscape-

71 level (within a 1-km radius around the point) environmental variables during spring 2013. Site-

72 level variables included percent cover for marsh, water, impervious surface (i.e., pavement,

73 structures, etc.), and bare ground. We used slightly modified Daubenmire (1959) cover classes

74 (i.e., cover classes: none, $0-1 \%, 1-5 \%, 5-25 \%, 25-50 \%, 50-75 \%, 75-95 \%,>95 \%$ ) to estimate

75 percent cover for each category within a 40-m radius. We quantified vegetation at the site-level

76 by selecting 10 random points stratified to represent all vegetation types present (i.e., riparian,

77 Sonoran Desert, marsh, etc.). Points were at least 10 meters apart and none of the points were

78 located in open water bodies or on roads. We recorded the proportion of random points where

79 vegetation was present at three height classes (low, below $0.6 \mathrm{~m}$; medium, 0.6-1.5 m; and high,

80 above $1.5 \mathrm{~m}$ ). We recorded percent canopy cover in four cardinal directions using a concave

81 densiometer, averaged the four readings per point, then averaged over the 10 points. At the

82 landscape level, we used ArcGIS 10.2 to quantify four land cover categories (i.e., impervious

83 surface, bare ground, water, and vegetation) around each sampling site (1-km radius). Land

84 cover categories were included in a land-cover classification dataset provided by CAP LTER,

85 which was generated from 2010 National Agriculture Imagery Program (NAIP) imagery using

86 methods detailed by Li, Myint, Zhang, Galletti, Zhang, et al. (2014).

\section{2.4. Data analyses}


To compare bird abundance and species richness across riparian habitat types through

89 time, we used Bayesian modeling since we had an unbalanced design. We generated two

90 Bayesian models (one for abundance and one for species richness) with Markov Chain Monte

91 Carlo (MCMC) using package rjags (Plummer, 2014) for program R stats version 3.2.1 (R Core

92 Team, 2013). The models followed a Poisson distribution (since data are univariate discrete

93 numbers) with a log link function. As input, we used data from all three observers for each year

94 and season. We used time as a covariate, and included a random effect for sites. We also

95 included a novice observer effect to our models, since observers tend to have lower than

96 expected count in the first year of conducting bird surveys (Kendall, Peterjohn, \& Sauer, 1996).

97 To compare how riparian type and season differ, we allowed parameters to vary by riparian type

98 and season. We assigned non-informative priors with a normal distribution to parameters and

99 novice observer effect. Since we had a small number of sites, for the site random effect, we

100 assigned a zero-centered distribution to the hierarchical prior and used a folded-Cauchy

101 distribution prior for its hyperparameter (precision). To be able to interpret intercepts and

102 random effect, we employed a post-sweeping method to compute identifiable intercepts and

103 random effect. For both models, we generated three independent MCMC chains and used

104 Gelman-Rubin diagnostic to evaluate chains convergence. To generate the posterior distribution,

105 we discarded the first 5,000 iterations to allow chains to converge, thinned by 25 to remove

106 autocorrelation, and generated 1,000 sampled values per chain. To test model fit, we plotted

107 replicated data against observed data.

To elucidate patterns in bird community structure, we used unconstrained ordinations,

109 specifically non-metric multidimensional scaling (NMDS; Clarke, 1993) with Bray-Curtis

110 distance, with square root and Wisconsin transformations, using program R stats version 3.1.1 
111 with the Vegan package (Oksanen, Blanchet, Kindt, Legendre, Minchin, et al., 2013). We

112 defined seasonal annual bird abundance per site as the maximum number of each species

113 recorded among three visits. We excluded species with less than five total individuals observed

114 during the 12 years, excluded species occurring only at one site, and removed unidentified

115 observations. Some bird species with low occurrences, that otherwise would be excluded, were

116 combined into the following feeding guilds: accipiters, falcons, fish eating raptors, terrestrial

117 raptors, cormorants, nighthawks, sandpipers, yellowlegs, and dowitchers. We computed

118 dispersion ellipses (based on standard deviation of weighted averages) to show separation of

119 riparian types in species space. To identify differences in bird assemblages across riparian types,

120 we generated ellipses for each type. To assess overall temporal change in community structure

121 and allow smoothing of short-term fluctuations, we combined all sites into 3-year moving

122 averages and generated ellipses around each temporal period (i.e., period 1 is the 3-year average

123 for years 2001, 2002, 2004; period 10 is the 3-year average for years 2011-2013).

To assess temporal change in bird diversity per riparian type, we computed diversity 125 profiles (Rényi's index family; Tóthmérész, 1995) using program R stats version 3.1.1 with 126 Vegan package (Oksanen et al., 2013). We compared profiles for early $(2001,2002,2004)$ and 127 recent time frames (2011-2013).

To determine which environmental variables described habitat differences across riparian

129 types, we used a permutation procedure to fit environmental variables onto spring bird ordination 130 of recent years (2011-2013). Because site-level variables were collected in spring 2013, and 131 landscape-level variables were based on remote-sensed images from 2010, we used only bird 
132 data from spring of 2011, 2012, and 2013 as input to generate the NMDS. Significant values of 133 environmental vectors revealed which variables characterized each riparian type.

134 3. Results

\subsection{Bird abundance, richness, seasonality, and community composition}

Bird community parameters varied seasonally and across riparian types. At perennial site

137 types, we found greater abundances in winter than in spring (Table 1; Fig. 2). Within each season, bird abundance and species richness were higher at perennial sites compared to ephemeral sites (Table 1; Fig. 2; Appendix A). Bird abundance was highest at perennialengineered sites during both seasons.

We also observed seasonal differences in riparian bird assemblages, with spring and

142 winter bird communities composed of different migratory species (Appendix B, top panel). We

143 interpreted a 3-dimensional solution for spring (NMDS stress $=19.9 \%$, linear fit $\mathrm{R}^{2}=71.3$ ), with

144 the third axis depicting seasonal differences in migrants. Species present in winter included 145 migratory waterfowl (i.e., Gadwall, Anas strepera; Common Merganser, Mergus merganser; and 146 American Wigeon, Anas americana) and marsh birds (i.e., Wilson's Snipe, Gallinago delicata).

147 Species common during spring included migratory riparian passerines (i.e., Yellow Warbler, 148 Setophaga petechia; Lucy’s Warbler, Oreothlypis luciae; Wilson’s Warbler, Cardellina pusilla; 149 and Bell's Vireo, Vireo bellii), doves (i.e., White-winged Dove, Zenaida asiatica), and 150 hummingbirds (i.e., Black-chinned Hummingbird, Archilochus alexandri).

The four riparian types supported different bird community compositions (Appendix B, 152 lower panels). The ordination for spring (NMDS stress $=18.1 \%$, linear fit $\left.\mathrm{R}^{2}=77.1\right)$ and 
153 ordination for winter $\left(\mathrm{NMDS}\right.$ stress $=18.7 \%$, linear fit $\left.\mathrm{R}^{2}=74.2\right)$ revealed 3-axis solutions. For

154 both ordinations, Axis 1 depicted differences in bird community structure based on water

155 presence (i.e., perennial or ephemeral); whereas, Axis 2 depicted differences based on degree of

156 human-modification (i.e., natural or ephemeral). Engineered sites supported more broadly

157 distributed generalists, such as Great-tailed Grackle (Quiscalus mexicanus), House Sparrow

158 (Passer domesticus), Yellow-rumped Warbler (Setophaga coronata), Mourning Dove (Zenaida

159 macroura), and European Starling (Sturnus vulgaris). Natural sites supported more specialist

160 species, such as Northern Cardinal (Cardinalis cardinalis), Bewick's Wren (Thryomanes

161 bewickii), and Black-throated Sparrow (Amphispiza bilineata). Sites with perennial water had

162 high numbers of birds associated with water such as waterfowl, shorebirds, Black Phoebe

163 (Sayornis nigricans), and Song Sparrow (Melospiza melodia); whereas, ephemeral sites

164 supported Sonoran Desert species such as Gambel's Quail (Callipepla gambelii), and Curved-

165 billed Thrasher (Toxostoma curvirostre).

166

167

168

169

170

171

172 types, with one exception: the perennial-engineered sites during spring had a slight increase in

173 bird abundance across time (Table 1). The greatest declines (over 50\%) in abundance and

174 richness over the 12 year period occurred in natural sites. For both seasons, abundance and 
175 species richness decreased annually at a greater rate in natural sites (6\% to $7 \%$ declines)

176 compared to engineered sites (1\% to $3.5 \%$ declines). During spring, abundance at ephemeral

177 sites decreased annually (around 6\% decline) at a greater rate than perennial sites (2.5\% decline);

178 whereas, ephemeral and perennial sites decreased similarly during winter (4\% to 5\% declines).

179 During both seasons, species richness at ephemeral sites decreased at similar annual rates (over

$5 \%$ declines) compared to perennial sites (over $4 \%$ declines).

We observed temporal shifts in the composition of the riparian bird community for both

182

183

184

185 186

seasons (Fig. 3). We interpreted a 3-dimensional solution for spring (NMDS stress = 13\%, linear fit $\mathrm{R}^{2}=88.4$ ) and 3-dimensional solution for winter (NMDS stress $=12.9 \%$, linear fit $\mathrm{R}^{2}=88.3$ ). As depicted by the trajectory of ellipses (representing the core of the bird community per temporal period), ordinations showed that riparian bird communities shifted toward assemblages found at ephemeral-engineered sites during both seasons.

Diversity profiles (Appendix D) indicated the riparian bird community has become less diverse through time across riparian types and seasons. We were unable to compare diversity profiles of early and recent time frames at perennial-natural sites in winter because their profiles did not rank consistently (illustrated by intersecting lines), thus not allowing comparisons.

\subsection{Habitat characteristics of riparian types}

We tested the fit of 12 environmental variables (Appendix E) onto the ordination for spring birds during recent years (3-axis solution, NMDS stress $=14.2 \%$, linear fit $\left.\mathrm{R}^{2}=85.2\right)$. We identified four site-level and four landscape-level variables that described differences in habitat characteristics among riparian types (Fig. 4). At the landscape-level, sites with perennial flows had more vegetation and water cover compared to ephemeral sites. Ephemeral-engineered sites 
197 had the greatest amount of impervious surface; whereas, ephemeral-natural sites had the greatest 198 amount of bare ground. At the site-level, perennial types had more water, canopy cover, and 199 marsh compared to ephemeral sites. Among the perennial types, natural sites had a greater 200 proportion of tall vegetation and dense canopy cover compared to engineered sites.

4. Discussion

Our study provides one of the very few assessments of decadal changes in urban bird communities (for global bird declines observed via long-term data see: Julliard, Jiguet, \&

204 Couvet, 2004; Clavel, Julliard, \& Devictor, 2011). In riparian zones of the greater Phoenix metropolitan area and surrounding Sonoran Desert region, we documented declines in both abundance and species richness, with declines exceeding 50\% at natural sites over a 12 -year

207 monitoring period (Table 1). Bird communities in Phoenix riparian sites have shifted toward 208 assemblages dominated by fewer, more abundant and more typical 'urban' species (Fig. 3).

209 However, even common, broadly distributed species also showed declines. Some of the species 210 we observed are declining regionally or nationally. Thus, potential explanations for these shifts 211 may include region-wide processes like drought or climate change. Alternatively, local land 212 cover changes, like urban expansion and urban intensification may contribute to species losses 213 via a variety of mechanisms including habitat loss and habitat degradation. We examine evidence 214 for each of these explanations and discuss implications for safeguarding or enhancing riparian 215 species diversity in cities.

\subsection{Declines in bird community parameters during the last decade}

One of the strengths of our study is the use of temporal rather than solely spatial 
219 richness, only temporal analyses allowed us to document that bird species richness dwindled by more than $2-8 \%$ per year. The benefit of a long-term study is to document individual fluctuations 221 and trends of species in a community (Picket et al., 2011).

Riparian bird diversity in Phoenix has declined due to decreases in both evenness and species 223 richness. This decline suggests that the bird community has shifted toward an assemblage 224 dominated by fewer more abundant species, a shift commonly found in other studies along 225 spatial urbanization gradients (Melles, Glenn, \& Martin, 2003; Shochat, Lerman, Anderies, 226 Warren, Faeth, et al., 2010). This decrease in both richness and evenness suggests that migratory 227 birds and specialists, which were common at the beginning of the study, have decreased in 228 abundance and some species have been lost or replaced by more abundant species.

Our results show that bird abundance has decreased for many different kinds of species.

230 Ballard, Geupel, Nur, and Gardali (2003) had similar findings in their 20-year mist-netting study 231 in central coastal California, with 16 of 31 species undergoing significant declines and no species 232 increasing in abundance. We document declining trends in both migratory and resident species, 233 and in typical urban 'avoiders' and urban 'invaders' (i.e., species that typically respond 234 differently to urbanization, Marzluff \& Rodewald, 2008). Both urban avoiders that migrate (e.g., 235 Brewer's Sparrow, Spizella breweri; Northern Cardinal, and Yellow Warbler) and urban 236 avoiders that are resident (e.g., Black-Tailed Gnatcatcher, Polioptila melanura; and Black237 Throated Sparrow) experience declining trends. The latter species are consistent with recently 238 observed patterns of decline among desert and aridland species across North America (Sauer, 239 Link, Fallon, Pardieck, \& Ziolkowski, 2013). It is more surprising, however, that we find 240 declines in many common resident, typical urban-dwelling species in our study (e.g., House 
241 Finch, Haemorhous mexicanus, Mourning Dove, and House Sparrow). Mourning Doves are the

242 most abundant species in our study and are widespread across the United States (Sauer et al.,

243 2013). Data from the North American Breeding Bird Survey indicate slight declines in Mourning

244 Doves of $0.4 \%$ per year (Sauer et al., 2013), suggesting that our findings are only partly

245 reflective of broader scale trends for that species. In our study, only Canada Geese (Branta

246 canadensis) increased over time, which mirrors the national trend for increases in urban geese

247 populations (Smith, Craven, \& Curtis, 1999). We suggest that future research address whether

248 these patterns indeed represent regional trends or patterns inherent to urban ecosystems.

\subsection{Drying conditions affect riparian habitats and birds}

Similar to global human burdens on freshwater, Arizona and the southwest USA are

251 projected to increase water demand and water supplies are projected to decrease due to climate

252 change (Hawkins \& Ellis, 2010). Arid regions throughout the world are projected to become

253 warmer and drier, leading to higher frequency and intensity of drought (IPCC, 2007). Bird

254 diversity is often associated with perennial flows in arid riparian systems (Merritt \& Bateman,

255 2012). Therefore, groundwater losses that negatively influence the distribution and quality of

256 riparian forests will also negatively affect resident and migratory bird habitat (Brand, Stromberg,

257 Goodrich, Dixon, Lansey, et al., 2011).

Wetlands in the arid southwest USA have experienced dramatic declines in extent

259 (Weisberg, Mortenson, \& Dilts, 2013). Within urban areas, discharge from municipal outflows

260 (e.g., storm drains) along arid streams can provide hydrological conditions necessary for

261 sustaining threatened wetland and riparian habitats (Bateman et al., 2015). A two year study

262 along the Salt River in Phoenix found that areas which maintain riparian and wetland habitats 
263 from both passive and active restoration have abundant and diverse biotic communities, 264 irrespective of the source of water (Bateman et al., 2015). Taken together, these studies 265 document the relative importance of water quantity for habitat and bird diversity.

In this study, Phoenix riparian sites with perennial flows are more similar in bird 267 community composition and support the greatest abundance of birds compared to sites with 268 ephemeral water. At the site-level, both perennial riparian types are associated with high levels 269 of water and wetland cover. As such, perennial sites harbor more aquatic and shoreline270 associated species compared to ephemeral sites. These birds may be attracted to resources like 271 food, water, and cover that may be lacking at drier sites. Habitat structure also varied between 272 the perennial riparian types, possibly accounting for why migratory songbirds were more 273 common in perennial-natural sites compared to perennial-engineered sites. Our data and other 274 studies from this arid region suggest that natural areas with tall vegetation and dense canopy 275 cover support songbird habitat, similar to reaches along the Salt River (Bateman et al., 2015) and 276 non-urban streams in central Arizona (Brand et al., 2011; Merritt \& Bateman, 2012).

277 Although high bird abundances at perennial sites suggest that areas with aquatic habitats 278 are important for maintaining urban biota, we did observe an important shift in bird community 279 composition over time. Interestingly, the composition of bird communities across all sites has 280 become more similar to the composition found at ephemeral-engineered sites. This could suggest 281 that even the perennial sites are experiencing habitat loss, which could contribute to the overall 282 reduction in abundance of riparian birds, as well as, the change in community assemblage over 283 time. 
In this study, we found the greatest decreases in birds at ephemeral compared to perennial

285 sites. Even though we found more birds and more species at perennial sites, the importance of

286 ephemeral riparian areas is not to be overlooked in aridland ecosystems (Katz, Denslow, and

287 Stromberg, 2012). For example, non-perennial streams may represent vegetation and habitat

288 available to both Sonoran Desert species and riparian obligate species. Future research should

289 investigate if the mechanisms for bird declines varies among riparian types.

\subsection{Land cover and habitat change}

291

Although we do not have direct measures of land cover change around our sites, Phoenix

292 has experienced both rapid urban expansion (Kane, Connors, \& Galletti, 2014) as well as urban

293 intensification over the past several decades (Stefanov, Netzband, Möller, Redman, \& Mack,

294 2007). In Phoenix and other metropolitan areas, urban areas are increasingly moving from a

295 patchwork of agriculture and rural/residential yards to become more 'filled in' by impervious

296 surfaces with low vegetation cover (Stefanov et al., 2007; Tratalos, Fuller, Warren, Davies, \&

297 Gaston, 2007). While for some species, the decline we observe may be part of regional trends,

298 declines in common, resident urban-dwelling species leads us to suspect that urbanization has

299 played a significant role. This view is bolstered by the clear shift in community composition that

300 we observe across riparian types toward the more urban-dwelling species found in ephemeral-

301 engineered sites. This suggests that urbanization in areas surrounding riparian sites is

302 contributing to declines in abundance and species richness as well as shifts in species

303 composition. Similarly, other studies have quantified shifts in bird communities related to the

304 modification of land cover. For example, a study in Great Britain found that urban intensification

305 or 'densification' is associated with declines in bird densities (Tratalos, Fuller, Evans, Davies, 
306 Newson, et al., 2007). Another study in Massachusetts documenting bird community shifts over

307150 years, found shifts toward more typical urban dwelling species and away from forest

308 specialist species during a period in which wooded urban areas became progressively more 309 densely populated (Strohbach et al., 2014).

In our study, riparian types with ephemeral water have features that describe the openness

311 of the habitat and support bird species associated with the Sonoran Desert (e.g., Gambel's Quail, 312 and Curve-billed Thrasher). However, the openness found in engineered sites is comprised of 313 impervious surfaces; whereas, natural sites have bare ground. Desert specialist species, such as

314 Phainopepla (Phainopepla nitens), are present only at ephemeral-natural sites, highlighting the 315 importance of preserving natural open spaces. A study in Berkeley, California, USA, suggested 316 that green spaces serve to mitigate for loss of biodiversity by supporting specialist species in 317 urban areas (Shultz, Tingley, \& Bowie, 2012). Perhaps natural sites in Phoenix may serve as 318 refugia for specialist species intolerant of a landscape dedicated to the built environment. We 319 suggest additional research evaluate species-habitat relations and document modification to 320 vegetation cover and open space over time.

\section{5. Conclusions}

322 Our results indicate that, over the last decade, several species have been lost, and many 323 common and rare birds are experiencing declining abundances in riparian zones of the greater 324 Phoenix metropolitan area and nearby surrounding Sonoran Desert. These declines tend to be 325 greater in more natural sites compared to human-influenced, engineered sites. Bird communities 326 respond to degree of water permanence in this arid city. Perennial sites are important because 327 they provide habitat for a range of species, including aquatic and marshland birds, as well as, 
328 migratory songbirds. Engineered riparian sites in Phoenix appear to be surrounded by greater 329 impervious surface cover and are associated with more typical urban-dwelling species. By 330 contrast, natural sites support more specialists such as migratory songbirds and Sonoran Desert 331 species. However, the decadal declines we found for species using these natural sites suggest that 332 they may be sensitive to increased urban expansion or intensification in the areas surrounding 333 natural riparian sites. Taken together, our study and others of riparian sites in Phoenix, suggest 334 the following measures to maintain diverse and abundant riparian bird communities in the city: 335 (1) preserving natural areas with high amounts of tall vegetation and dense canopy cover (for 336 migratory songbirds), (2) retaining natural areas with bare ground (for upland Sonoran Desert 337 species), and (3) maintaining or restoring habitats with perennial flows to support a diverse urban 338 bird assemblage. 


\section{References}

Aronson, M. F. J., La Sorte, F. A., Nilon, C. H., Katti, M., Goddard, M. A., Lepczyk, C. A., Warren, P. S., Williams, N. S. G., Cilliers, S., Clarkson, B., Dobbs, C., Dolan, R., Hedblom, M., Klotz, S., Kooijmans, J. L., Kühn, I., MacGregor-Fors, I., McDonnell, M., Mörtberg, U., Pyšek, P., Siebert, S., Sushinsky, J., Werner, P., \& Winter, M. (2014). A global analysis of the impacts of urbanization on bird and plant diversity reveals key anthropogenic drivers. Proceedings of the Royal Society B: Biological Sciences, 281(1780), 20133330. doi:10.1098/rspb.2013.3330

Ballard, G., Geupel, G. R., Nur, N., \& Gardali, T. (2003). Long-term declines and decadal patterns in population trends of songbirds in western North America, 1979-1999. The Condor, 105(4), 737-755. doi:10.1650/7131

Bateman, H. L., Stromberg, J. C., Banville, M. J., Makings, E., Scott, B. D., Suchy, A., \& Wolkis, D. (2015). Novel water sources restore plant and animal communities along an urban river. Ecohydrology, 8, 792-811. doi:10.1002/eco.1560

Bernhardt, E. S., \& Palmer, M. A. (2007). Restoring streams in an urbanizing world. Freshwater Biology, 52(4), 738-751. doi:10.1111/j.1365-2427.2006.01718.x

Bibby, C. J., Burgess, N. D., Hill, D. A., \& Mustoe, S. H. (2000). Bird census techniques (2nd ed.). Great Britain: Academic Press.

Brand, L. A., Stromberg, J. C., Goodrich, D. C., Dixon, M. D., Lansey, K., Kang, D., Brookshire, D. S., \& Cerasale, D. J. (2011). Projecting avian response to linked changes in groundwater and riparian floodplain vegetation along a dryland river: a scenario analysis. Ecohydrology, 4(1), 130-142. doi:10.1002/eco.143

Clarke, K. R. (1993). Non-parametric multivariate analyses of changes in community structure. Australian Journal of Ecology, 18(1), 117-143.

Clavel, J., Julliard, R., \& Devictor, V. (2011). Worldwide decline of specialist species: toward a global functional homogenization? Frontiers in Ecology and the Environment, 9(4), 222-228. doi:10.1890/080216

Czech, B., Krausman, P. R., \& Devers, P. K. (2000). Economic associations among causes of species endangerment in the United States Associations among causes of species endangerment in the United States reflect the integration of economic sectors, supporting the theory and evidence that economic growth proceeds at the competitive exclusion of nonhuman species in the aggregate. BioScience, 50(7), 593-601. doi:10.1641/0006-3568(2000)050[0593:EAACOS] 2.0.CO;2

Daubenmire, R. (1959). A canopy-coverage method of vegetational analysis. Northwest Science, 33(1), 43-64.

De Caceres, M., \& Legendre, P. (2009). Associations between species and groups of sites: Indices and statistical inference. Ecology, 90(12), 35663-3574. doi:10.1890/08-1823.1 
Gober, P., Wentz, E. A., Lant, T., Tschudi, M. K., \& Kirkwood, C. W. (2011). WaterSim: A simulation model for urban water planning in Phoenix, Arizona, USA. Environment and Planning B: Planning and Design, 38(2), 197-215. doi:10.1068/b36075

Hawkins, T. W., \& Ellis, A. W. (2010). The dependence of streamflow on antecedent subsurface moisture in an arid climate. Journal of Arid Environments, 74(1), 75-86.

doi:10.1016/j.jaridenv.2009.07.003

Hobbs, F., \& Stoops, N. (2002). U.S. Census Bureau, census 2000 special reports, series CENSR-4: demographic trends in the $20^{\text {th }}$ century. Washington, DC: U.S. Government Printing Office. Retrieved from https://www.census.gov/prod/2002pubs/censr-4.pdf

Homer, C. G., Dewitz, J. A., Yang, L., Jin, S., Danielson, P., Xian, G., Coulston, J., Herold, N. D., Wickham, J. D., \& Megown, K. (2015). Completion of the 2011 National Land Cover Database for the conterminous United States-Representing a decade of land cover change information. Photogrammetric Engineering and Remote Sensing, 81(5), 345-354. Retrieved from http://www.mrlc.gov/nlcd2011.php

Intergovernmental Panel on Climate Change (IPCC). (2007). Climate change 2007: the physical science basis. In S. Solomon, D. Qin, M. Manning, Z. Chen, M. Marquis, K. B. Averiyt, M. Tignor, \& H. Miller (Eds). Contribution of Working Group I to the Fourth Assessment Report of the Intergovernmental Panel on Climate Change. Cambridge, UK: Cambridge University Press. Retrieved from https://www.ipcc.ch/publications_and_data/ar4/wg1/en/contents.html

Julliard, R., Jiguet, F., \& Couvet, D. (2004). Evidence for the impact of global warming on the longterm population dynamics of common birds. Proceedings of the Royal Society B: Biological Sciences, 271(Suppl 6), S490-S492. doi:10.1098/rsbl.2004.0229

Kane, K., Connors, J. P., \& Galletti, C. S. (2014). Beyond fragmentation at the fringe: A pathdependent, high-resolution analysis of urban land cover in Phoenix, Arizona. Applied Geography, 52, 123-134. doi:10.1016/j.apgeog.2014.05.002

Katz, G. L., Denslow, M. W., \& Stromberg, J. C. (2012). The Goldilocks effect: intermittent streams sustain more plant species than those with perennial or ephemeral flow. Freshwater Biology, 57(3), 467-480. doi:10.1111/j.1365-2427.2011.02714.x

Kendall, W. L., Peterjohn, B. G., \& Sauer, J. R. (1996). First-time observer effects in the North American Breeding Bird Survey. Auk, 113(4), 823-829. doi:10.2307/4088860

Knopf, F. L., \& Samson, F. B. (1994). Scale perspectives on avian diversity in western riparian ecosystems. Conservation Biology, 8(3), 669-676. doi:10.1046/j.1523-1739.1994.08030669.x

Li, X., Myint, S. W., Zhang, Y., Galletti, C., Zhang, X., \& Turner, B. L. II. (2014). Object-based land-cover classification for metropolitan Phoenix, Arizona, using aerial photography.

International Journal of Applied Earth Observation and Geoinformation, 33, 321-30. doi:10.1016/j.jag.2014.04.018

Magurran, A. E., Baillie, S. R., Buckland, S. T., Dick, J. M., Elston, D. A., Scott, E. M., Smith, R. I., Somerfield, P. J., \& Watt, A. D. (2010). Long-term datasets in biodiversity research and 
monitoring: assessing change in ecological communities through time. Trends in Ecology \& Evolution, 25(10), 574-582. doi:10.1016/j.tree.2010.06.016

Marzluff, J. M. (2001). Worldwide urbanization and its effects on birds. In J. M. Marzluff, R. Bowman, \& R. Donnelly (Eds.), Avian Ecology and Conservation in an Urbanizing World (pp. 19-47). Springer US. doi:10.1007/978-1-4615-1531-9_2

Marzluff, J. M., \& Rodewald, A. D. (2008). Conserving biodiversity in urbanizing areas: Nontraditional views from a bird's perspective. Cities and the Environment, 1(2), article 6.

McKinney, M. L. (2002). Urbanization, biodiversity, and conservation: The impacts of urbanization on native species are poorly studied, but educating a highly urbanized human population about these impacts can greatly improve species conservation in all ecosystems. BioScience, 52(10), 883-890. doi:10.1641/0006-3568(2002)052[0883:UBAC]2.0.CO;2

Melles, S., Glenn, S., \& Martin, K. (2003). Urban bird diversity and landscape complexity: Species-environment associations along a multiscale habitat gradient. Conservation Ecology, 7(1), 5. http://www.consecol.org/vol7/iss 1/art5/

Merritt, D. M., \& Bateman, H. L. (2012). Linking streamflow and groundwater to avian habitat in a desert riparian system. Ecological Applications, 22(7), 1973-1988. doi:10.1890/12-0303.1

Naiman, R. J., Decamps, H., \& Pollock, M. (1993). The role of riparian corridors in maintaining regional biodiversity. Ecological Applications, 3(2), 209-212. doi:10.2307/1941822

Oksanen, J., Blanchet, F. G., Kindt, R., Legendre, P., Minchin, P. R., O’Hara, R. B., Simpson, G. L., Solymos, P., Henry, M., Stevens, H., \& Wagner, H. (2013). Vegan: community ecology package. R package version 2.0-10. Retrieved from http://CRAN.R-project.org/package=vegan

Paul, M. J., \& Meyer, J. L. (2001). Streams in the urban landscape. Annual Review of Ecology and Systematics, 32, 333-365. doi:10.1146/annurev.ecolsys.32.081501.114040

Pickett, S. T. A., Cadenasso, M. L., Grove, J. M., Boone, C. G., Groffman, P. M., Irwin, E., Kaushal, S. S., Marshall, V., McGrath, B. P., Nilon, C. H., Pouyat, R. V., Szlavecz, K., Troy, A., $\&$ Warren, P. (2011). Urban ecological systems: Scientific foundations and a decade of progress. Journal of Environmental Management, 92(3), 331-362. doi:10.1016/j.jenvman.2010.08.022

Plummer, M. (2014). rjags: Bayesian graphical models using MCMC. R package version 3-13. Retrieved from http://CRAN.R-project.org/package=rjags

Pyle, P., \& DeSante, D. (2013). List of North American birds and alpha codes according to American Ornithologists' Union taxonomy through the $54^{\text {th }}$ AOU Supplement. Retrieved from http://www.birdpop.org/alphacodes.htm

R Core Team. (2013). R: A language and environment for statistical computing. R Foundation for Statistical Computing, Vienna, Austria. ISBN 3-900051-07-0. Retrieved from http://www.Rproject.org/ 
Sauer, J. R., Link, W. A., Fallon, J. E., Pardieck, K. L., \& Ziolkowski, D. J. Jr. (2013). The North American Breeding Bird Survey 1966-2011: Summary analysis and species accounts. North American Fauna, 79, 1-32. doi:10.3996/nafa.79.0001

Shochat, E., Lerman, S. B., Anderies, J. M., Warren, P. S., Faeth, S. H., \& Nilon, C. H. (2010). Invasion, competition, and biodiversity loss in urban ecosystems. BioScience, 60(3), 199-208. doi:10.1525/bio.2010.60.3.6

Shultz, A. J., Tingley, M. W., \& Bowie, R. C. K. (2012). A century of avian community turnover in an urban green space in northern California. The Condor, 114(2), 258-267. doi:10.1525/cond.2012.110029

Sibley, D. A. (2000). National Audubon Society, the Sibley guide to birds. New York, NY: Alfred A. Knopf, Inc.

Smith, A. E., Craven, S. R., \& Curtis, P. D. (1999). Managing Canada geese in urban environments. Jack Berryman Institute Publication 16, and Cornell University Cooperative Extension, Ithaca, N.Y.

Stefanov, W. L., Netzband, M., Möller, M. S., Redman, C. L., \& Mack, C. (2007). Phoenix, Arizona, USA: Applications of remote sensing in a rapidly urbanizing desert region. In M. Netzband, W. L. Stefanov, \& C. L. Redman (Eds.), Applied Remote Sensing for Urban Planning, Governance and Sustainability (pp. 137-164). Springer Berlin Heidelberg. doi:10.1007/978-3540-68009-3_7

Strohbach, M. W., Hrycyna, A., \& Warren, P. S. (2014). 150 years of changes in bird life in Cambridge, Massachusetts from 1860 to 2012. The Wilson Journal of Ornithology, 126(2), 192206. doi:10.1676/13-127.1

Tóthmérész, B. (1995). Comparison of different methods for diversity ordering. Journal of Vegetation Science, 6(2), 283-290.

Tratalos, J., Fuller, R. A., Evans, K. L., Davies, R. G., Newson, S. E., Greenwood, J. J. D., \& Gaston, K. J. (2007). Bird densities are associated with household densities. Global Change Biology, 13(8), 1685-1695. doi:10.1111/j.1365-2486.2007.01390.x

Tratalos, J., Fuller, R. A., Warren, P. H., Davies, R. G., \& Gaston, K. J. (2007). Urban form, biodiversity potential and ecosystem services. Landscape and Urban Planning, 83(4), 308-317. doi:10.1016/j.landurbplan.2007.05.003

U.S. Census Bureau. (2015). State and County QuickFacts. Last Revised: Thursday, 28-May2015. Retrieved from http://www.census.gov/

Weisberg, P. J., Mortenson, S. G., \& Dilts, T. E. (2013). Gallery forest or herbaceous wetland? The need for multi-target perspectives in riparian restoration planning. Restoration Ecology, 21(1), 12-16. doi:10.1111/j.1526-100X.2012.00907.x 


\section{List of Tables}

Table 1. Bird abundance during spring and winter at 12 sites across four riparian types in central Arizona, USA. 
Table 1. Bird abundance during spring and winter at 12 sites across four riparian types in central Arizona, USA, based on Bayesian analyses. Riparian types vary by water permanence and degree of human influence: ephemeral-engineered (EE), ephemeral-natural (EN), perennialengineered (PE), and perennial-natural (PN). Mean and trend in abundance with lower and upper credible intervals (CIs) derived from a Bayesian model (model fit $\mathrm{R}^{2}=0.41$, model under predicted points at high abundance) for the beginning (2001) and the end (2013) of the study period. Trend is the percent change in abundance per year, or the total percent change in abundance over the period of the study (12 years), with significant changes in bold.

\begin{tabular}{|c|c|c|c|c|}
\hline \multirow[b]{3}{*}{ Riparian type } & \multicolumn{4}{|c|}{ Spring } \\
\hline & Early (2001) & Recent (2013) & Per year & Over 12 yrs \\
\hline & Mean (CIs) & Mean (CIs) & Trend in \% (CIs) & Trend in \% (CIs) \\
\hline ephemeral-engineered & $23.9(22.3,25.6)$ & $14.8(13.7,15.9)$ & $-3.9(-4.9,-3.0)$ & $-38.2(-45.5,-30.2)$ \\
\hline ephemeral-natural & $20.4(18.2,22.7)$ & $7.3(6.3,8.3)$ & $-8.2(-9.8,-6.6)$ & $-64.3(-71.1,-55.8)$ \\
\hline perennial-engineered & $49.1(46.7,51.7)$ & $53.4(50.7,56.3)$ & $0.7(0.0,1.4)$ & $8.9(0.2,18.3)$ \\
\hline perennial-natural & $25.6(23.6,27.7)$ & $12.7(11.6,13.9)$ & $-5.7(-6.9,-4.6)$ & $-50.5(-57.4,-42.9)$ \\
\hline Engineered $(\mathrm{EE}+\mathrm{PE})$ & $34.3(32.8,35.8)$ & $28.1(24.9,31.5)$ & $-1.6(-2.3,-1.0)$ & $-18.0(-24.0,-11.8)$ \\
\hline Natural $(\mathrm{EN}+\mathrm{PN})$ & $22.8(21.4,24.4)$ & $9.6(7.9,11.7)$ & $-7.0(-8.0,-5.9)$ & $-58.0(-63.1,-52.0)$ \\
\hline Perennial $(\mathrm{PE}+\mathrm{PN})$ & $35.5(33.8,37.2)$ & $26.0(22.8,29.7)$ & $-2.5(-3.2,-1.9)$ & $-26.6(-32.6,-20.2)$ \\
\hline \multirow[t]{3}{*}{ Ephemeral $(\mathrm{EE}+\mathrm{EN})$} & $22.1(20.6,23.5)$ & $10.4(8.6,12.5)$ & $-6.1(-7.1,-5.1)$ & $-53.0(-58.5,-46.9)$ \\
\hline & \multicolumn{4}{|c|}{ Winter } \\
\hline & Early (2001) & Recent (2013) & Per year & Over 12 yrs \\
\hline Riparian type & Mean (CIs) & Mean (CIs) & Trend in \% (CIs) & Trend in \% (CIs) \\
\hline ephemeral-engineered & $24.2(22.6,26.0)$ & $13.7(12.6,14.8)$ & $-4.6(-5.6,-3.7)$ & $-43.4(-50.2,-36.3)$ \\
\hline ephemeral-natural & $12.9(11.3,14.8)$ & $6.8(5.8,7.8)$ & $-5.2(-7.2,-3.3)$ & $-47.6(-59.2,-33.3)$ \\
\hline perennial-engineered & $80.5(77.3,83.9)$ & $65.4(62.5,68.3)$ & $-1.7(-2.3,-1.1)$ & $-18.8(-24.2,-12.9)$ \\
\hline perennial-natural & $46.8(43.8,49.9)$ & $19.0(17.6,20.5)$ & $-7.2(-8.1,-6.3)$ & $-59.4(-63.9,-54.4)$ \\
\hline Engineered $(\mathrm{EE}+\mathrm{PE})$ & $44.2(42.4,46.0)$ & $29.9(26.7,33.5)$ & $-3.2(-3.8,-2.6)$ & $-32.2(-37.0,-27.1)$ \\
\hline Natural $(\mathrm{EN}+\mathrm{PN})$ & $24.6(22.8,26.5)$ & $11.3(9.2,14.0)$ & $-6.2(-7.3,-5.2)$ & $-53.9(-59.9,-47.1)$ \\
\hline Perennial $(\mathrm{PE}+\mathrm{PN})$ & $61.4(59.1,63.9)$ & $35.3(31.7,39.3)$ & $-4.5(-5.1,-4.0)$ & $-42.6(-46.3,-38.5)$ \\
\hline Ephemeral $(\mathrm{EE}+\mathrm{EN})$ & $17.7(16.4,19.1)$ & $9.6(7.8,11.9)$ & $-4.9(-6.0,-3.9)$ & $-45.5(-52.5,-37.7)$ \\
\hline
\end{tabular}




\section{List of Figures}

Fig. 1. Bird sampling locations at 12 riparian sites in the greater Phoenix metropolitan area and surrounding Sonoran Desert, Arizona, USA.

Fig. 2. Spring and winter bird abundances (3-year moving averages) and species richness (3-year moving averages) with standard error bars per riparian type (12 sites) in central Arizona, USA.

Fig. 3. Ordinations of the riparian bird community showing temporal shifts in community structure during spring and winter over the period of the study (12 years) at 12 sites in central Arizona, USA.

Fig. 4. Significant environmental variables (arrows) describing habitat characteristics across four riparian types (12 sites in central Arizona, USA) are depicted on spring bird ordination of recent years (2011-2013). 


\section{Figures}

Fig. 1. Bird sampling locations at 12 riparian sites in the greater Phoenix metropolitan area and surrounding Sonoran Desert, Arizona, USA. Sampling locations are overlaid on a map of 2011 land cover of the region, modified from the National Land Cover Database (Homer, Dewitz, Yang, Jin, Danielson, et al., 2015). Riparian sampling locations differ in water permanence (ephemeral or perennial) and degree of human influence (engineered or natural).

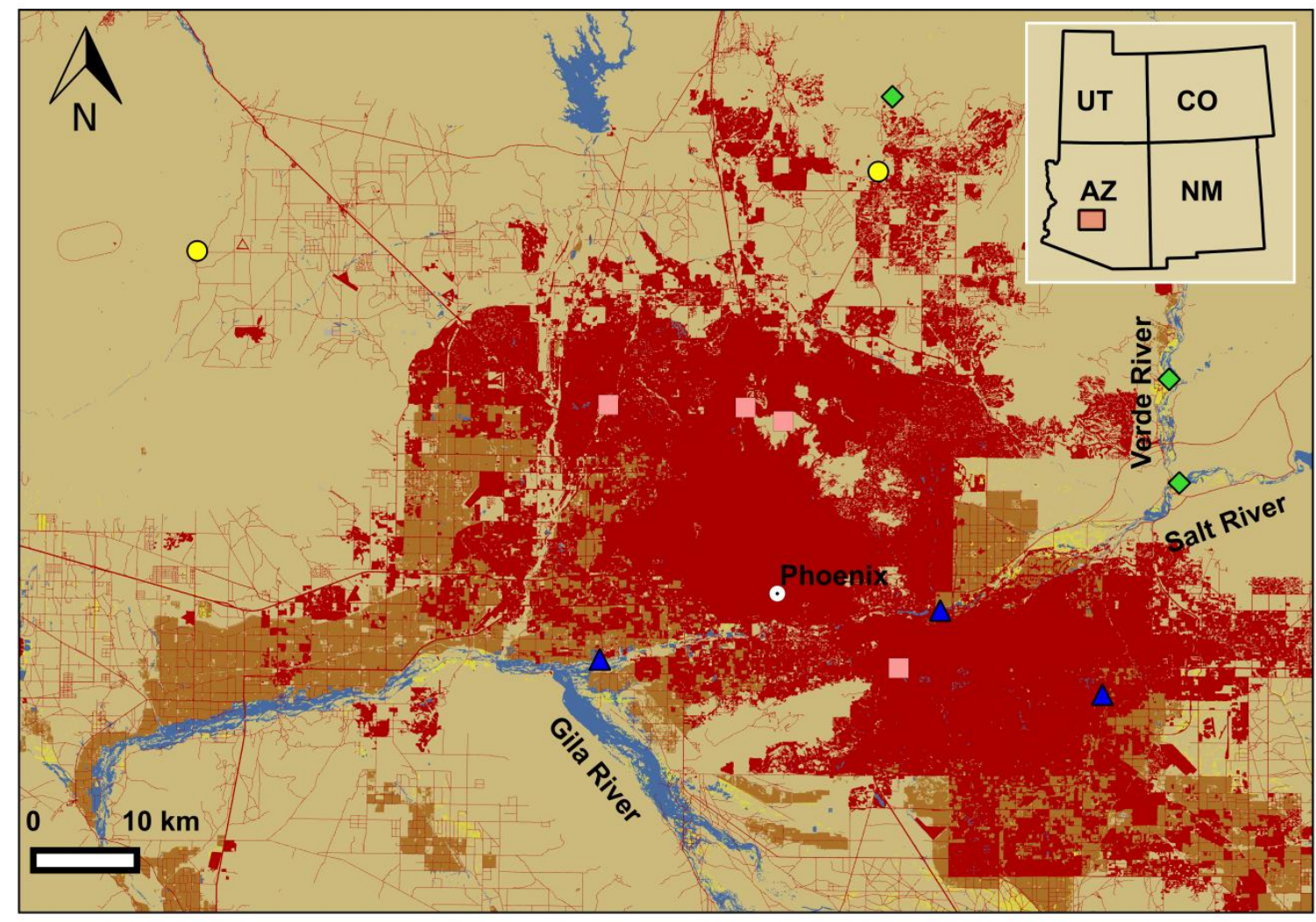

\section{Land Cover Categories Sampling Locations}

open water, wetlands

developed

Sonoran desert pasture, hay cultivated crops
- ephemeral-engineered (EE)

ephemeral-natural (EN)

$\triangle$ perennial-engineered (PE)

$\diamond$ perennial-natural ( $P N)$ 
Fig. 2. Spring and winter bird abundances (3-year moving averages) and species richness (3-year moving averages) with standard error bars per riparian type (12 sites) in central Arizona, USA. Abundance is maximum number of each species observed (among three seasonal visits) per site and averaged across the 3 years. Period 1 is the 3-year average for years 2001, 2002, 2004; period 10 is the 3-year average for years 2011-2013. Riparian types vary by water permanence and degree of human influence: ephemeral-engineered (EE), ephemeral-natural (EN), perennialengineered (PE), and perennial-natural (PN).
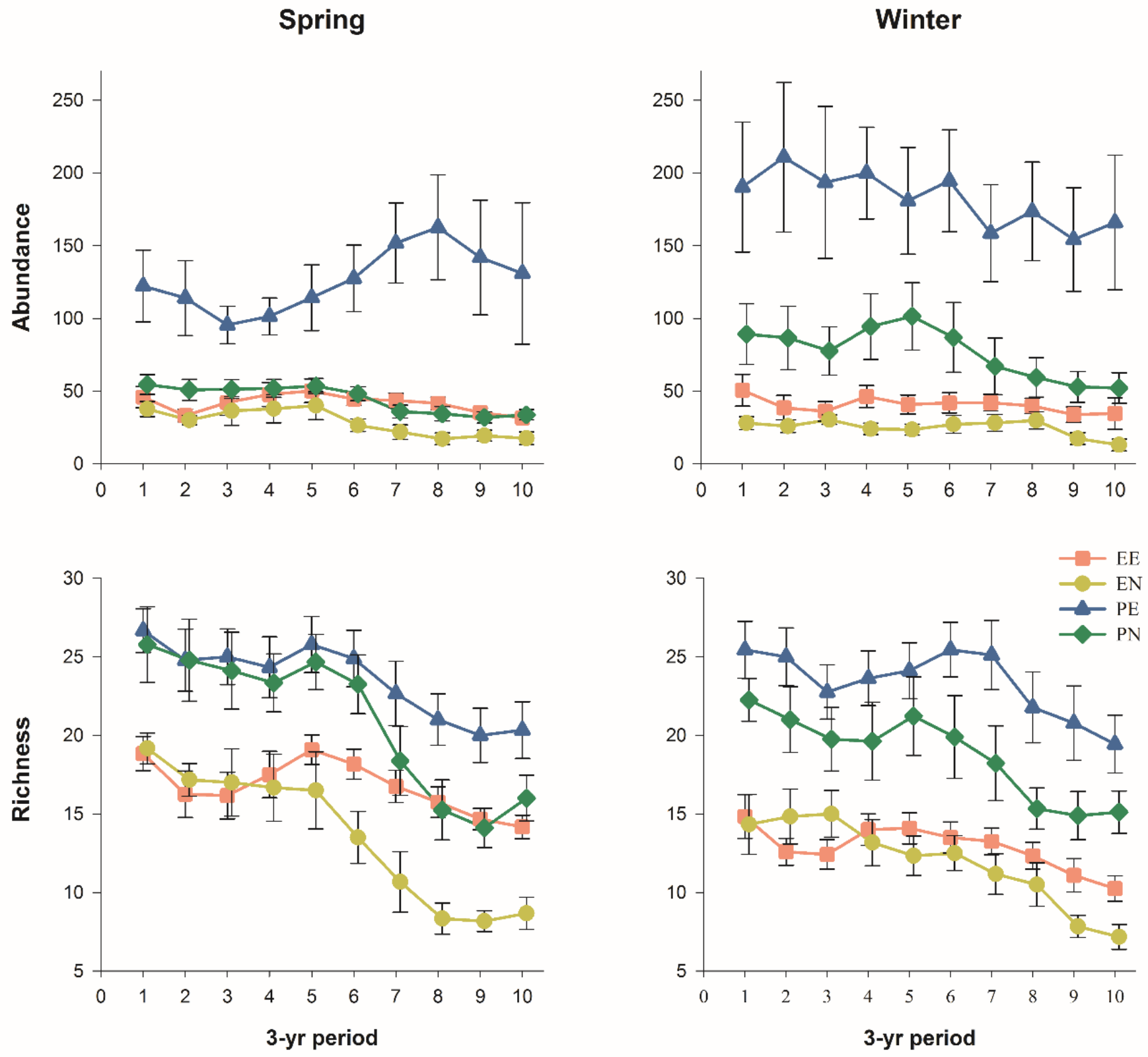
Fig. 3. Ordinations of the riparian bird community showing temporal shifts in community structure during spring and winter over the period of the study (12 years) at 12 sites in central Arizona, USA. Riparian types vary by water permanence and degree of human influence: ephemeral-engineered (EE), ephemeral-natural (EN), perennial-engineered (PE), and perennial-natural (PN). Ellipses represent the core of the overall riparian bird community for each temporal period (3-year moving averages), from period 1 (average of 2001, 2002, 2004, depicted in light yellow) to period 10 (average of 2011-2013, depicted in dark red). Trajectory of ellipses depicts the change in bird assemblages over time.

Spring Temporal NMDS

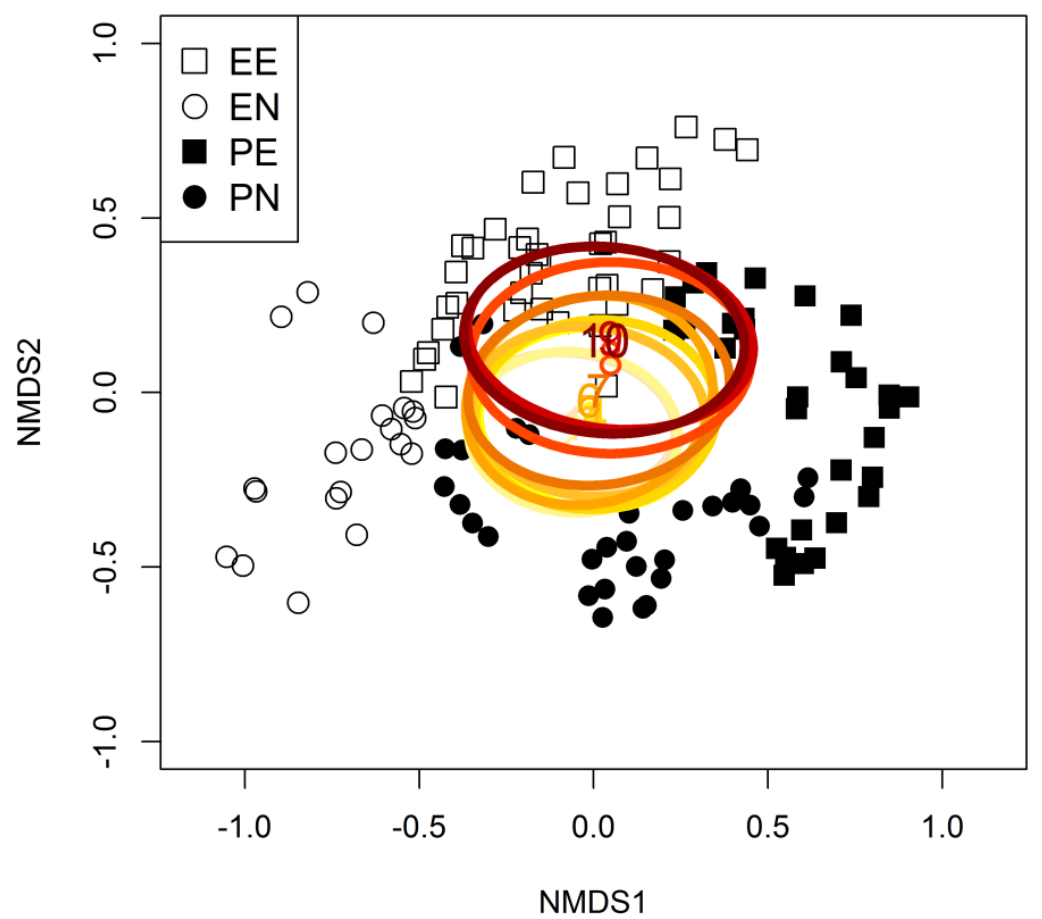

Winter Temporal NMDS

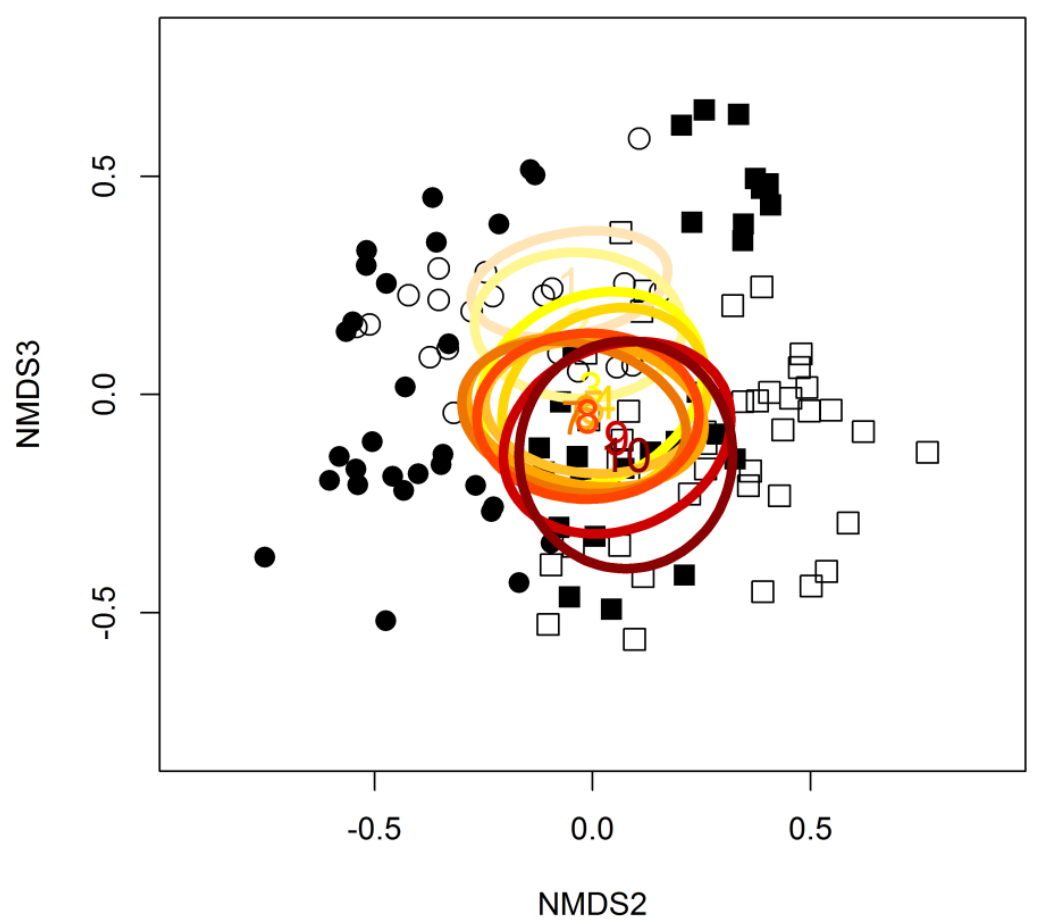


Fig. 4. Significant environmental variables (arrows) describing habitat characteristics across four riparian types (12 sites in central Arizona, USA) are depicted on spring bird ordination of recent years (2011-2013). The direction of the arrow indicates an increase of that variable. Refer to Appendix E for environmental variables codes and descriptions. Ellipses represent the core of the bird communities for each riparian type. Riparian types vary by water permanence and degree of human influence: ephemeral-engineered (EE), ephemeral-natural (EN), perennial-engineered (PE), and perennial-natural (PN). Axis 1 and 2 of ordination show differences at the landscape- and site-levels across riparian types. Axis 3 of ordination shows differences among the perennial types at the site-level.

Environmental NMDS, Axis $1 \& 2$

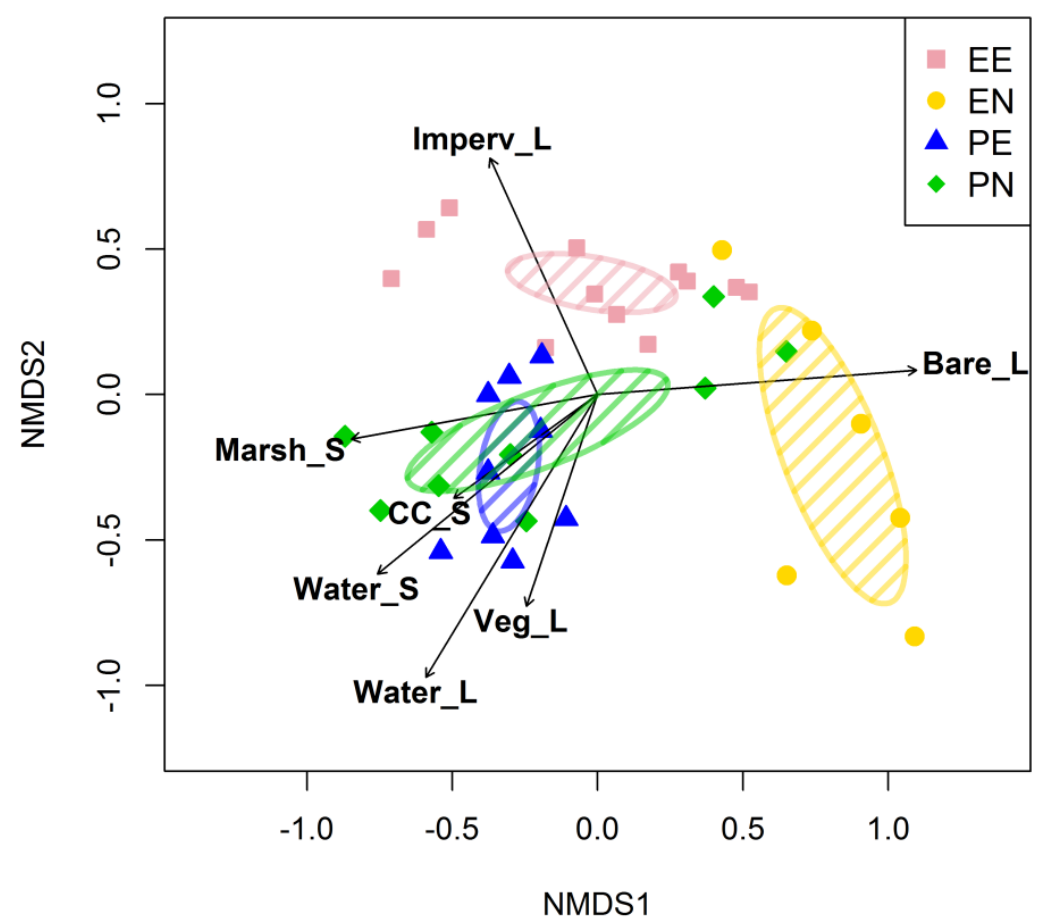

Environmental NMDS, Axis $1 \& 3$

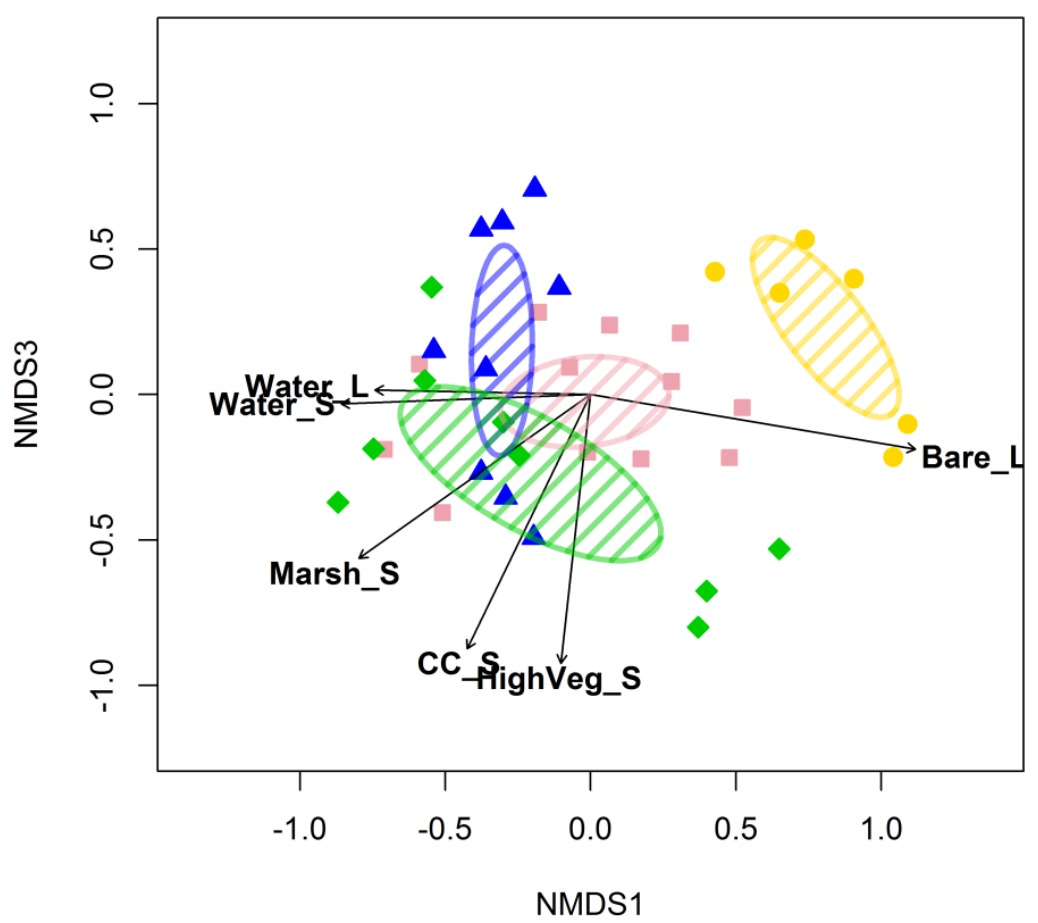




\section{List of Appendices}

Appendix A. Bird species richness during spring and winter at 12 sites across four riparian types in central Arizona, USA.

Appendix B. Ordinations of bird communities at 12 sites across four riparian types in central Arizona, USA.

Appendix C. List of bird common and scientific names and four-letter alpha codes of species observed at 12 riparian sites from 2001-2013 in central Arizona, USA.

Appendix D. Diversity profiles of bird communities found at four riparian types (12 sites) in central Arizona, USA, for spring and winter of early and recent time frames.

Appendix E. Environmental variables measured at 12 sites across four riparian types in central Arizona, USA. 
Appendix A. Bird species richness during spring and winter at 12 sites across four riparian types in central Arizona, USA, based on Bayesian analyses. Riparian types vary by water permanence and degree of human influence: ephemeral-engineered (EE), ephemeral-natural (EN), perennialengineered (PE), and perennial-natural (PN). Mean and trend in species richness with lower and upper credible intervals (CIs) derived from a Bayesian model (model fit $\mathrm{R}^{2}=0.45$ ) for the beginning (2001) and the end (2013) of the study period. Trend is the percent change in richness per year, or the total percent change in richness over the period of the study (12 years), with significant changes in bold.

\begin{tabular}{|c|c|c|c|c|}
\hline \multirow[b]{3}{*}{ Riparian type } & \multicolumn{4}{|c|}{ Spring } \\
\hline & Early (2001) & Recent (2013) & Per year & Over 12 yrs \\
\hline & Mean (CIs) & Mean (CIs) & Trend in $\%$ (CIs) & Trend in \% (CIs) \\
\hline ephemeral-engineered & $9.5(8.5,10.6)$ & $6.5(5.7,7.2)$ & $-3.2(-4.7,-1.7)$ & $-32.0(-43.7,-18.3)$ \\
\hline ephemeral-natural & $9.7(8.3,11.4)$ & $3.6(2.9,4.4)$ & $-7.8(-10.2,-5.5)$ & $-62.5(-72.6,-49.6)$ \\
\hline perennial-engineered & $13.6(12.2,15.1)$ & $9.1(8.1,10.2)$ & $-3.3(-4.7,-1.8)$ & $-33.0(-43.8,-19.5)$ \\
\hline perennial-natural & $13.1(11.7,14.6)$ & $6.6(5.8,7.6)$ & $-5.5(-7.1,-3.9)$ & $-49.3(-58.6,-38.0)$ \\
\hline Engineered $(\mathrm{EE}+\mathrm{PE})$ & $11.4(10.5,12.2)$ & $7.7(6.2,9.5)$ & $-3.2(-4.3,-2.1)$ & $-32.5(-40.9,-22.7)$ \\
\hline Natural $(\mathrm{EN}+\mathrm{PN})$ & $11.3(10.3,12.4)$ & $4.9(3.7,6.4)$ & $-6.7(-8.1,-5.3)$ & $-56.4(-63.7,-48.2)$ \\
\hline Perennial $(\mathrm{PE}+\mathrm{PN})$ & $13.3(12.3,14.4)$ & $7.8(6.2,9.6)$ & $-4.4(-5.5,-3.3)$ & $-41.7(-49.4,-33.1)$ \\
\hline \multirow[t]{3}{*}{ Ephemeral $(\mathrm{EE}+\mathrm{EN})$} & $9.6(8.7,10.6)$ & $4.9(3.6,6.4)$ & $-5.5(-7.0,-4.1)$ & $-49.5(-58.2,-39.8)$ \\
\hline & \multicolumn{4}{|c|}{ Winter } \\
\hline & Early (2001) & Recent (2013) & Per year & Over 12 yrs \\
\hline Riparian type & Mean (CIs) & Mean (CIs) & Trend in \% (CIs) & Trend in \% (CIs) \\
\hline ephemeral-engineered & $8.4(7.4,9.5)$ & $4.8(4.2,5.5)$ & $-4.5(-6.2,-2.8)$ & $-42.7(-53.8,-29.1)$ \\
\hline ephemeral-natural & $7.3(6.0,8.7)$ & $3.5(2.8,4.3)$ & $-6.0(-8.5,-3.4)$ & $-52.2(-65.7,-33.9)$ \\
\hline perennial-engineered & $14.5(13.1,16.0)$ & $10.8(9.7,12.0)$ & $-2.5(-3.9,-1.1)$ & $-25.9(-37.6,-12.2)$ \\
\hline perennial-natural & $12.1(10.7,13.8)$ & $6.1(5.3,7.0)$ & $-5.5(-7.3,-3.8)$ & $-49.6(-59.7,-37.3)$ \\
\hline Engineered $(\mathrm{EE}+\mathrm{PE})$ & $11.0(10.2,11.9)$ & $7.2(5.8,9.0)$ & $-3.5(-4.6,-2.4)$ & $-34.8(-43.4,-24.9)$ \\
\hline Natural (EN + PN) & $9.4(8.4,10.5)$ & $4.6(3.4,6.3)$ & $-5.8(-7.3,-4.2)$ & $-50.9(-60.0,-40.3)$ \\
\hline Perennial $(\mathrm{PE}+\mathrm{PN})$ & $13.3(12.3,14.4)$ & $8.1(6.5,10.1)$ & $-4.0(-5.1,-2.9)$ & $-38.8(-46.8,-29.7)$ \\
\hline Ephemeral $(\mathrm{EE}+\mathrm{EN})$ & $7.8(7.0,8.7)$ & $4.1(3.0,5.6)$ & $-5.2(-6.8,-3.6)$ & $-47.6(-57.1,-35.9)$ \\
\hline
\end{tabular}


Appendix B. Ordinations of bird communities at 12 sites across four riparian types in central Arizona, USA. Riparian types vary by water permanence and degree of human influence: ephemeral-engineered (EE), ephemeral-natural (EN), perennial-engineered (PE), and perennial-natural (PN). Community composition varied by seasons and types during spring and winter from 2001 to 2013 . Top panel ordination axis 3 separates bird species (four-letter alpha codes from Pyle \& DeSante, 2013; Appendix E) by seasons. On lower panels, axis 1 separates birds based on water presence and axis 2 separates birds based on degree of human influence. Ellipses on lower panels represent the core of bird communities per type.

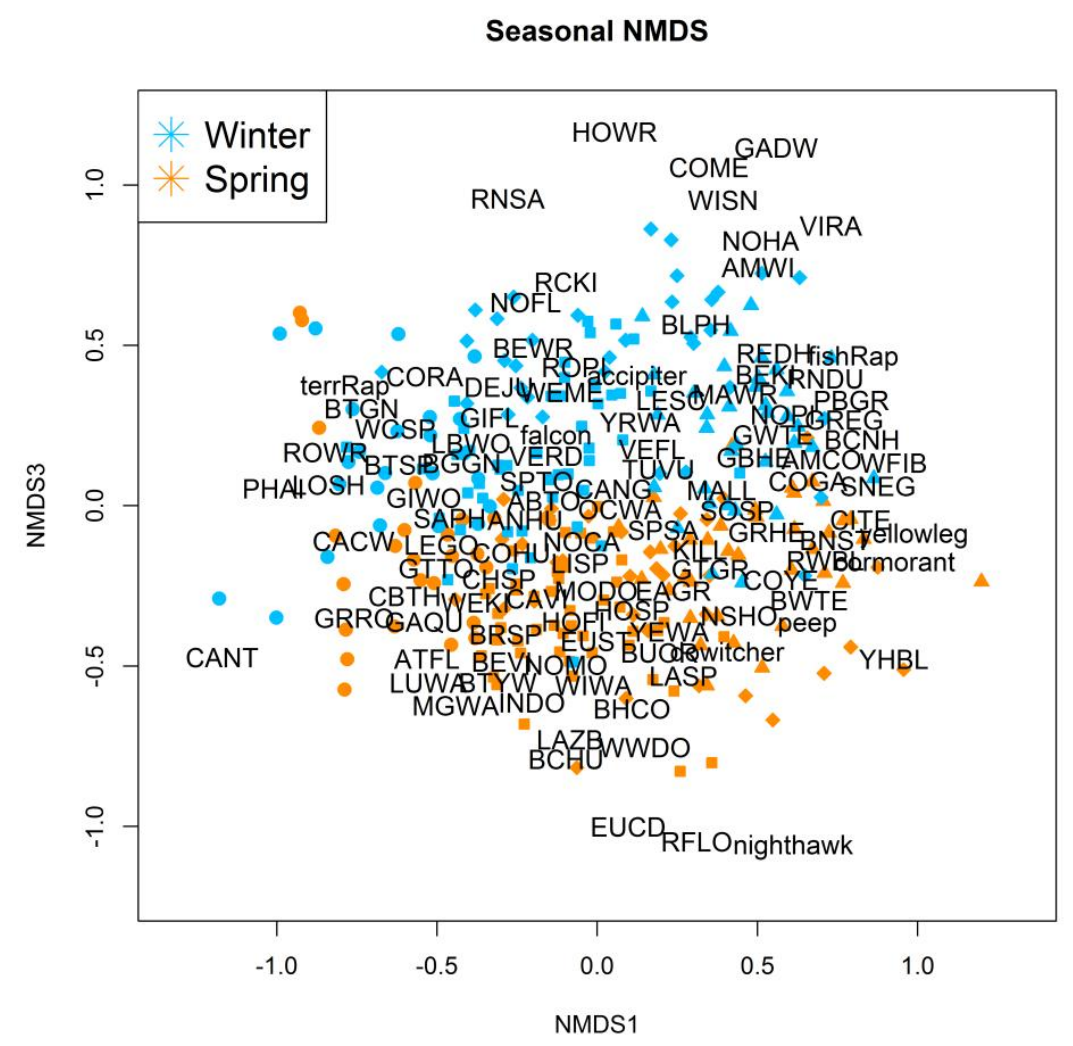




\section{Spring Riparian Type NMDS}

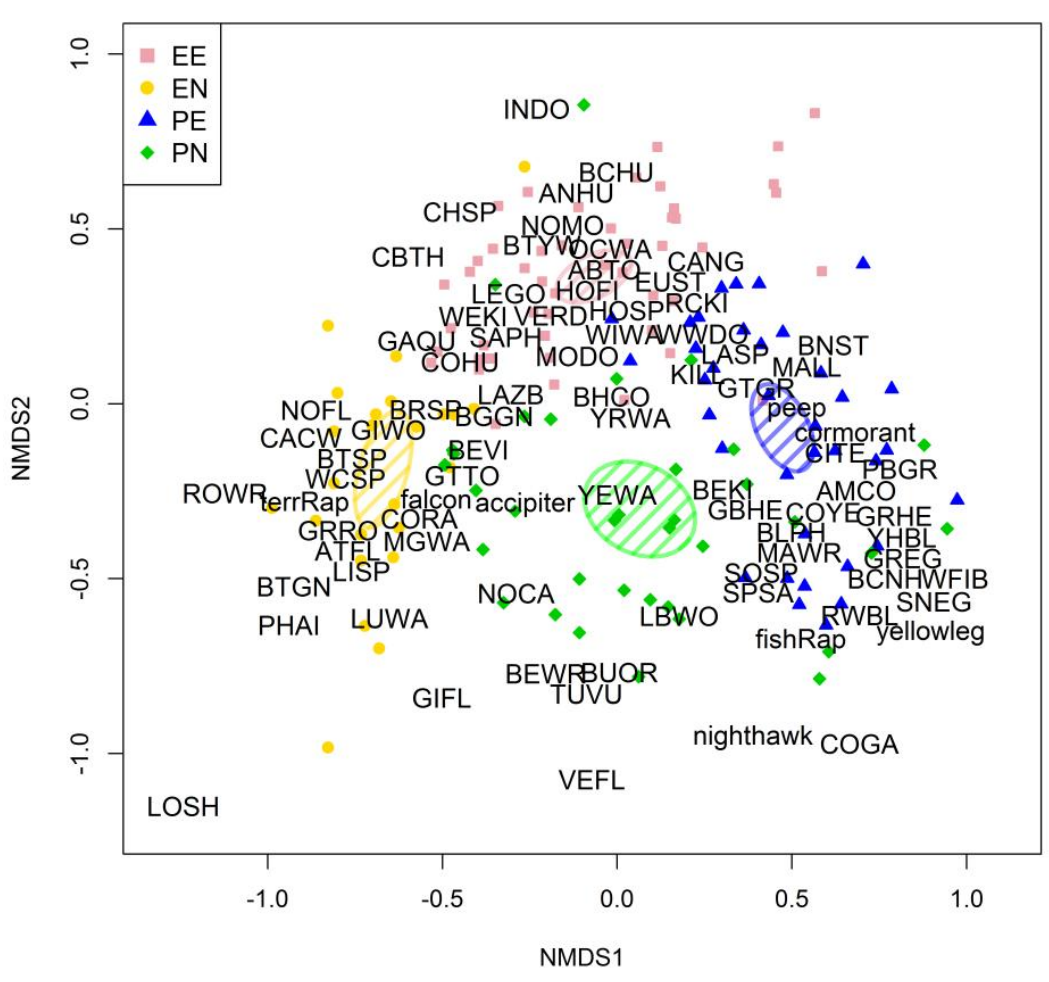

\section{Winter Riparian Type NMDS}

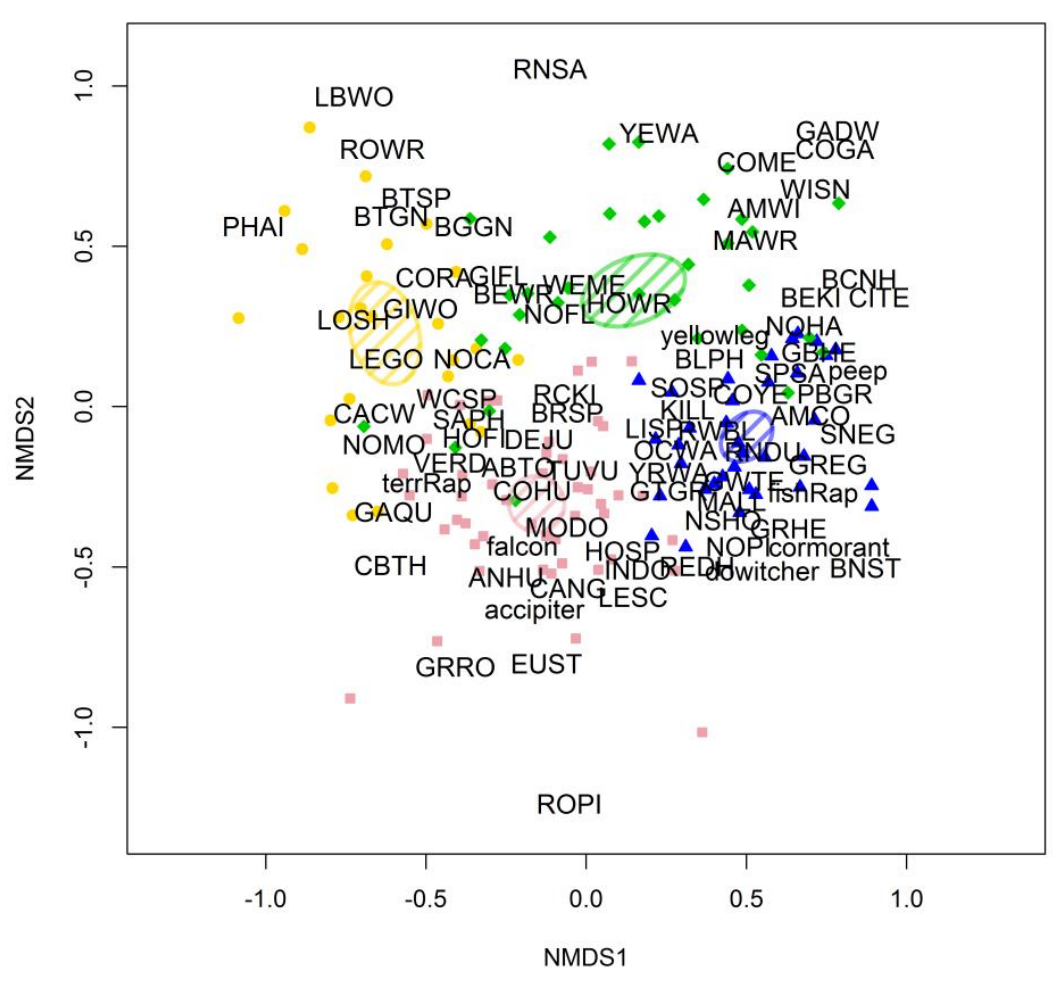


Appendix C. List of bird common and scientific names and four-letter alpha codes (according to Pyle \& DeSante, 2013) of species observed at 12 riparian sites from 2001-2013 in central Arizona, USA. For each species, early (2001, 2002, 2004) and recent (20112013) abundances for spring and winter are presented. Abundance is the sum for all sites of the maximum number of each species observed among three seasonal annual visits per site during a 3-year period (early and recent). Abundances with zero values indicate species was observed in study but not during early or recent period. Bolding indicates species with significantly different $(\mathrm{p}<0.05)$ counts in early versus recent period based on Pearson's Phi Coefficient of Association generated using program R stats version 3.1.1 with indicspecies package (De Caceres \& Legendre, 2009).

\begin{tabular}{|c|c|c|c|c|c|c|}
\hline \multirow[b]{2}{*}{ Common name } & \multirow[b]{2}{*}{ Scientific name } & \multirow[b]{2}{*}{ Code } & \multicolumn{2}{|c|}{ Spring } & \multicolumn{2}{|c|}{ Winter } \\
\hline & & & $\begin{array}{c}\text { Early } \\
\text { abundance }\end{array}$ & $\begin{array}{c}\text { Recent } \\
\text { abundance }\end{array}$ & $\begin{array}{c}\text { Early } \\
\text { abundance }\end{array}$ & $\begin{array}{c}\text { Recent } \\
\text { abundance }\end{array}$ \\
\hline Abert's Towhee & Melozone aberti & ABTO & 58 & 55 & 68 & 50 \\
\hline Acorn Woodpecker & Melanerpes formicivorus & ACWO & 0 & 1 & 0 & 0 \\
\hline American Avocet & Recurvirostra americana & AMAV & 10 & 10 & 0 & 0 \\
\hline American Bittern & Botaurus lentiginosus & AMBI & 0 & 0 & 1 & 0 \\
\hline American Coot & Fulica americana & $\mathrm{AMCO}$ & 40 & 13 & 123 & 30 \\
\hline American Crow & Corvus brachyrhynchos & AMCR & 0 & 1 & 0 & 0 \\
\hline American Goldfinch & Spinus tristis & AMGO & 0 & 2 & 11 & 0 \\
\hline American Kestrel & Falco sparverius & AMKE & 3 & 0 & 5 & 3 \\
\hline American Pipit & Anthus rubescens & AMPI & 0 & 0 & 0 & 0 \\
\hline American Wigeon & Anas americana & AMWI & 0 & 5 & 94 & 22 \\
\hline Anna's Hummingbird & Calypte anna & ANHU & 28 & 25 & 38 & 30 \\
\hline
\end{tabular}




\begin{tabular}{|c|c|c|c|c|c|}
\hline Ash-throated Flycatcher & Myiarchus cinerascens & ATFL & 24 & 4 & 3 \\
\hline Bald Eagle & Haliaeetus leucocephalus & BAEA & 2 & 0 & 4 \\
\hline Bank Swallow & Riparia riparia & BANS & 0 & 0 & 0 \\
\hline Barn Swallow & Hirundo rustica & BARS & 0 & 0 & 0 \\
\hline Bell's Vireo & Vireo bellii & BEVI & 10 & 4 & 0 \\
\hline Belted Kingfisher & Megaceryle alcyon & BEKI & 7 & 5 & 11 \\
\hline Bendire's Thrasher & Toxostoma bendirei & BETH & 1 & 0 & 0 \\
\hline Bewick's Wren & Thryomanes bewickii & BEWR & 8 & 1 & 6 \\
\hline Black Phoebe & Sayornis nigricans & BLPH & 11 & 3 & 20 \\
\hline Black Vulture & Coragyps atratus & BLVU & 2 & 0 & 0 \\
\hline Black-and-white Warbler & Mniotilta varia & BAWW & 0 & 0 & 1 \\
\hline Black-chinned Hummingbird & Archilochus alexandri & $\mathrm{BCHU}$ & 11 & 1 & 0 \\
\hline Black-chinned Sparrow & Spizella atrogularis & BCSP & 0 & 0 & 0 \\
\hline Black-crowned Night Heron & Nycticorax nycticorax & $\mathrm{BCNH}$ & 24 & 2 & 38 \\
\hline Black-headed Grosbeak & Pheucticus melanocephalus & BHGR & 0 & 0 & 0 \\
\hline Black-necked Stilt & Himantopus mexicanus & BNST & 55 & 5 & 27 \\
\hline Black-tailed Gnatcatcher & Polioptila melanura & BTGN & 15 & 2 & 18 \\
\hline Black-throated Gray Warbler & Setophaga nigrescens & BTYW & 0 & 0 & 1 \\
\hline
\end{tabular}




Black-throated Sparrow
Blue-gray Gnatcatcher
Blue-winged Teal
Brewer's Blackbird
Brewer's Sparrow
Bridled Titmouse
Bronzed Cowbird
Brown Pelican
Brown-crested Flycatcher
Brown-headed Cowbird
Bufflehead
Bullock's Oriole
Burrowing Owl
Bushtit
Cactus Wren
Canada Goose
Canvasback
Canyon Towhee

Amphispiza bilineata

Polioptila caerulea

Anas discors

Euphagus cyanocephalus

Spizella breweri

Baeolophus wollweberi

Molothrus aeneus

Pelecanus occidentalis

Myiarchus tyrannulus

Molothrus ater

Bucephala albeola

Icterus bullockii

Athene cunicularia

Psaltriparus minimus

Campylorhynchus brunneicapillus

Branta canadensis

Aythya valisineria

Melozone fusca

$\begin{array}{lc}\text { BTSP } & \mathbf{2 6} \\ \text { BGGN } & 5 \\ \text { BWTE } & 4 \\ \text { BRBL } & 6 \\ \text { BRSP } & \mathbf{1 0 3} \\ \text { BRTI } & 0 \\ \text { BROC } & 0 \\ \text { BRPE } & 0 \\ \text { BCFL } & 1 \\ \text { BHCO } & 58 \\ \text { BUFF } & 0 \\ \text { BUOR } & 7 \\ \text { BUOW } & 0 \\ \text { BUSH } & 2 \\ \text { CACW } & \mathbf{2 2} \\ \text { CANG } & \mathbf{0} \\ \text { CANV } & 0 \\ \text { CANT } & 0\end{array}$

17

3

2

0

0

0

0

0

1

0

6

0

0

0

0

8

172

7

2 


Canyon Wren
Cassin's Vireo
Cattle Egret
Chestnut-collared Longsp
Chinese Goose / Domes
Goose
Chipping Sparrow
Cinnamon Teal
Cliff Swallow
Common Gallinule
Common Goldeneye
Common Merganser
Common Nighthawk
Common Raven
Common Yellowthroat
Cooper's Hawk
Cordilleran Flycatcher
Costa's Hummingbird

Catherpes mexicanus

\begin{tabular}{|c|c|c|c|}
\hline CANW & 0 & 0 & 0 \\
\hline CAVI & 2 & 0 & 3 \\
\hline CAEG & 0 & 0 & 0 \\
\hline CCLO & 0 & 0 & 3 \\
\hline CHGO & 0 & 0 & 0 \\
\hline CHSP & 2 & 2 & 0 \\
\hline CITE & 10 & 10 & 4 \\
\hline CLSW & 0 & 0 & 0 \\
\hline COGA & 9 & 2 & 6 \\
\hline COGO & 0 & 0 & 0 \\
\hline COME & 0 & 0 & 3 \\
\hline CONI & 0 & 8 & 0 \\
\hline CORA & 18 & 12 & 21 \\
\hline COYE & 17 & 17 & 18 \\
\hline $\mathrm{COHA}$ & 2 & 5 & 1 \\
\hline COFL & 1 & 1 & 0 \\
\hline $\mathrm{COHU}$ & 10 & 3 & 8 \\
\hline
\end{tabular}


Crissal Thrasher

Curve-billed Thrasher

Dark Eyed Junco

Domestic Duck

Domestic Greylag Goose

Double-crested Cormorant

Downy Woodpecker

Eared Grebe

Eurasian Collared- Dove

European Starling

Gadwall

Gambel's Quail

Gila Woodpecker

Gilded Flicker

Glossy Ibis

Gray Flycatcher

Great Blue Heron

Great Egret
Toxostoma crissale

Toxostoma curvirostre

Junco hyemalis

Anas platyrhyncha domesticus

Anser anser

Phalacrocorax auritus

Picoides pubescens

Podiceps nigricollis

Streptopelia decaocto

Sturnus vulgaris

Anas strepera

Callipepla gambelii

Melanerpes uropygialis

Colaptes chrysoides

Plegadis falcinellus

Empidonax wrightii

Ardea herodias

Ardea alba

\begin{tabular}{|c|c|c|c|}
\hline CRTH & 0 & 0 & 0 \\
\hline CBTH & 13 & 22 & 20 \\
\hline DEJU & 0 & 0 & 22 \\
\hline DODU & 0 & 0 & 0 \\
\hline DOGO & 0 & 13 & 0 \\
\hline DCCO & 26 & 46 & 61 \\
\hline DOWO & 0 & 0 & 1 \\
\hline EAGR & 3 & 1 & 0 \\
\hline EUCD & 0 & 2 & 0 \\
\hline EUST & 5 & 10 & 5 \\
\hline GADW & 2 & 0 & 0 \\
\hline GAQU & 75 & 64 & 26 \\
\hline GIWO & 21 & 4 & 18 \\
\hline GIFL & 0 & 1 & 2 \\
\hline GLIB & 0 & 0 & 0 \\
\hline GRFL & 0 & 0 & 0 \\
\hline GBHE & 34 & 84 & 43 \\
\hline GREG & 30 & 20 & 78 \\
\hline
\end{tabular}




Great Horned Owl
Greater Roadrunner
Greater Yellowlegs
Great-tailed Grackle
Green Heron
Green-tailed Towhee
Green-winged Teal
Hairy Woodpecker
Hammond's Flycatcher
Harris' Hawk
Hermit Thrush
Hermit Warbler
Hooded Merganser
Hooded Oriole
Horned Lark
House Finch
House Sparrow
House Wren

Bubo virginianus

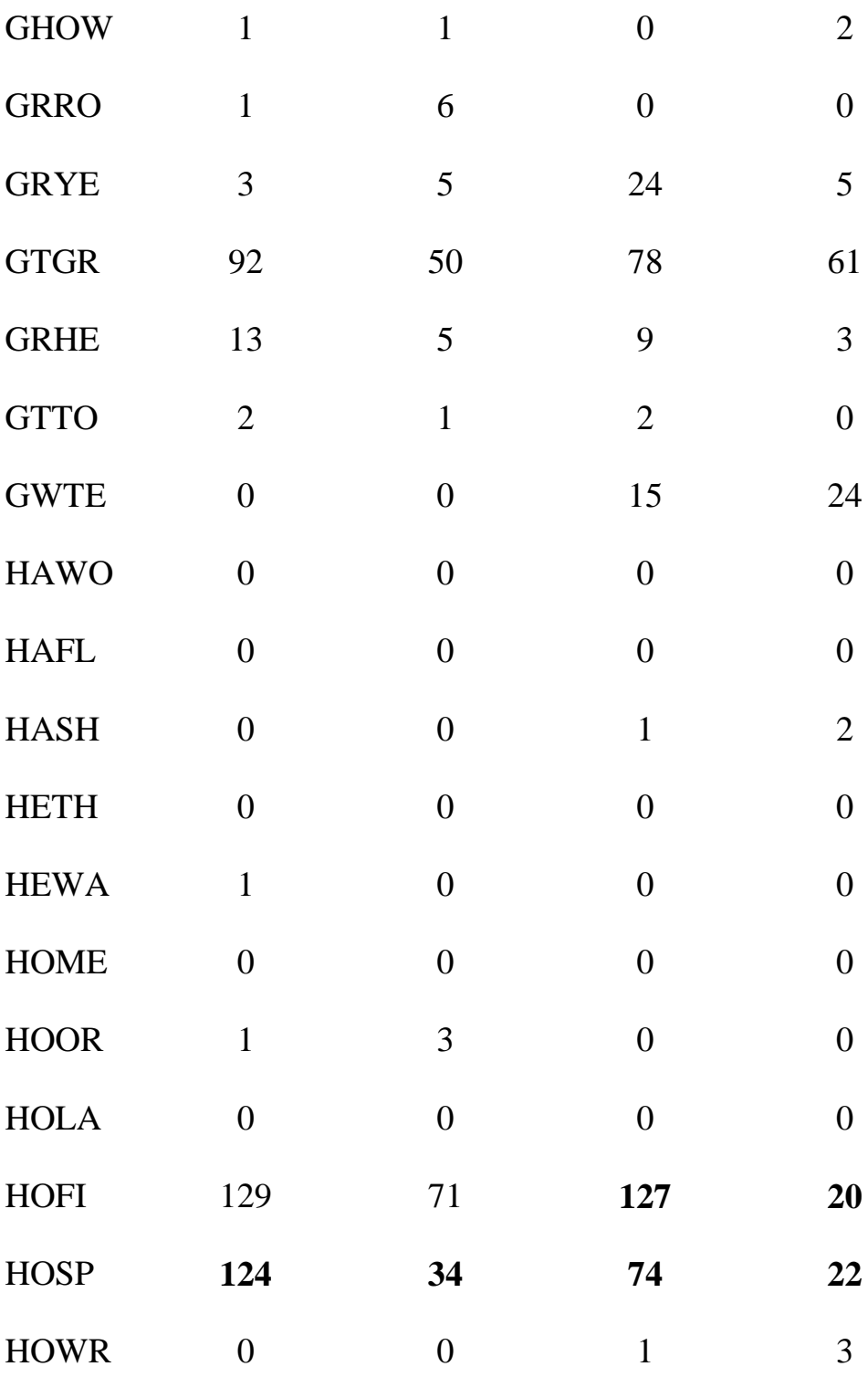




\begin{tabular}{|c|c|c|c|c|c|}
\hline Inca Dove & Columbina inca & INDO & 11 & 2 & 5 \\
\hline Killdeer & Charadrius vociferus & KILL & 76 & 57 & 83 \\
\hline Ladder-backed Woodpecker & Picoides scalaris & LBWO & 8 & 4 & 10 \\
\hline Lark Sparrow & Chondestes grammacus & LASP & 3 & 14 & 0 \\
\hline Lazuli Bunting & Passerina amoena & LAZB & 3 & 1 & 0 \\
\hline Least Sandpiper & Calidris minutilla & LESA & 37 & 0 & 81 \\
\hline Lesser Goldfinch & Spinus psaltria & LEGO & 6 & 23 & 3 \\
\hline Lesser Nighthawk & Chordeiles acutipennis & LENI & 0 & 8 & 0 \\
\hline Lesser Scaup & Aythya affinis & LESC & 0 & 0 & 0 \\
\hline Lesser Yellowlegs & Tringa flavipes & LEYE & 0 & 0 & 0 \\
\hline Lincoln's Sparrow & Melospiza lincolnii & LISP & 1 & 0 & 7 \\
\hline Little Blue Heron & Egretta caerulea & LBHE & 0 & 0 & 2 \\
\hline Loggerhead Shrike & Lanius ludovicianus & LOSH & 3 & 0 & 6 \\
\hline Long-billed Curlew & Numenius americanus & $\mathrm{LBCU}$ & 0 & 0 & 0 \\
\hline Long-billed Dowitcher & Limnodromus scolopaceus & LBDO & 48 & 200 & 36 \\
\hline Lucy's Warbler & Oreothlypis luciae & LUWA & 15 & 10 & 0 \\
\hline MacGillivray's Warbler & Geothlypis tolmiei & MGWA & 8 & $\mathbf{0}$ & 0 \\
\hline Magnolia Warbler & Setophaga magnolia & MAWA & 0 & 0 & 0 \\
\hline
\end{tabular}




\begin{tabular}{|c|c|c|c|c|c|}
\hline Mallard & Anas platyrhynchos & MALL & 109 & 96 & 161 \\
\hline Marsh Wren & Cistothorus palustris & MAWR & 6 & 1 & 16 \\
\hline Merlin & Falco columbarius & MERL & 1 & 1 & 0 \\
\hline Mountain Bluebird & Sialia currucoides & MOBL & 0 & 0 & 0 \\
\hline Mourning Dove & Zenaida macroura & MODO & 102 & 46 & 98 \\
\hline Neotropic Cormorant & Phalacrocorax brasilianus & NECO & 6 & 33 & 9 \\
\hline Northern Cardinal & Cardinalis cardinalis & NOCA & 20 & 1 & 7 \\
\hline Northern Flicker & Colaptes auratus & NOFL & 6 & 0 & 12 \\
\hline Northern Harrier & Circus cyaneus & NOHA & 0 & 0 & 2 \\
\hline Northern Mockingbird & Mimus polyglottos & NOMO & 17 & 9 & 12 \\
\hline Northern Pintail & Anas acuta & NOPI & 0 & 1 & 235 \\
\hline Northern Rough-winged Swallow & Stelgidopteryx serripennis & NRWS & 0 & 0 & 0 \\
\hline Northern Shoveler & Anas clypeata & NSHO & 7 & 39 & 56 \\
\hline Orange-crowned Warbler & Oreothlypis celata & OCWA & 9 & 8 & 26 \\
\hline Osprey & Pandion haliaetus & OSPR & 1 & 1 & 2 \\
\hline Peregrine Falcon & Falco peregrinus & PEFA & 1 & 0 & 2 \\
\hline Phainopepla & Phainopepla nitens & PHAI & 9 & 3 & 19 \\
\hline Pied-billed Grebe & Podilymbus podiceps & PBGR & 17 & $\mathbf{0}$ & 33 \\
\hline
\end{tabular}


Pine Siskin

Plumbeous Vireo

Pyrrhuloxia

Redhead

Red-naped Sapsucker

Red-tailed Hawk

Red-winged Blackbird

Ring-necked Duck

Rock Pigeon

Rock Wren

Rosy-faced Lovebird

Ruby-crowned Kinglet

Ruddy Duck

Rufous-crowned Sparrow

Savannah Sparrow

Say's Phoebe

Sharp-shinned Hawk

Snow Goose
Spinus pinus

Vireo plumbeus

Cardinalis sinuatus

Aythya americana

Sphyrapicus nuchalis

Buteo jamaicensis

Agelaius phoeniceus

Aythya collaris

Columba livia

Salpinctes obsoletus

Agapornis roseicollis

Regulus calendula

Oxyura jamaicensis

Aimophila ruficeps

Passerculus sandwichensis

Sayornis saya

Accipiter striatus

Chen caerulescens

\begin{tabular}{|c|c|c|c|}
\hline PISI & 0 & 0 & 0 \\
\hline PLVI & 0 & 1 & 0 \\
\hline PYRR & 0 & 0 & 0 \\
\hline REDH & 0 & 0 & 6 \\
\hline RNSA & 0 & 0 & 1 \\
\hline RTHA & 9 & 5 & 21 \\
\hline RWBL & 118 & 50 & 62 \\
\hline RNDU & 0 & 9 & 35 \\
\hline ROPI & 2 & 0 & 0 \\
\hline ROWR & 4 & 1 & 4 \\
\hline RFLO & 0 & 3 & 0 \\
\hline RCKI & 2 & 0 & 23 \\
\hline RUDU & 1 & 0 & 9 \\
\hline RCSP & 1 & 0 & 0 \\
\hline SAVS & 0 & 0 & 0 \\
\hline SAPH & 6 & 1 & 7 \\
\hline SSHA & 0 & 0 & 1 \\
\hline SNGO & 0 & 5 & 0 \\
\hline
\end{tabular}




Snowy Egret
Song Sparrow
Sora
Spotted Sandpiper
Spotted Towhee
Summer Tanager
Swamp Sparrow
Townsend's Warbler
Tree Swallow
Turkey Vulture
Vaux's Swift
Verdin
Vermilion Flycatcher
Vesper Sparrow
Violet-green Swallow
Virginia Rail
Virginia's Warbler
Warbling Vireo

Egretta thula

Melospiza melodia

Porzana carolina

Actitis macularius

Pipilo maculatus

Piranga rubra

Melospiza georgiana

Setophaga townsendi

Tachycineta bicolor

Cathartes aura

Chaetura vauxi

Auriparus flaviceps

Pyrocephalus rubinus

Pooecetes gramineus

Tachycineta thalassina

Rallus limicola

Oreothlypis virginiae

Vireo gilvus

\begin{tabular}{|c|c|c|c|}
\hline SNEG & 30 & 11 & 126 \\
\hline SOSP & 43 & 26 & 57 \\
\hline SORA & 0 & 0 & 0 \\
\hline SPSA & 4 & 2 & 12 \\
\hline SPTO & 2 & 0 & 4 \\
\hline SUTA & 0 & 0 & 0 \\
\hline SWSP & 0 & 0 & 3 \\
\hline TOWA & 2 & 0 & 0 \\
\hline TRES & 0 & 0 & 0 \\
\hline TUVU & 17 & 7 & 3 \\
\hline VASW & 0 & 0 & 0 \\
\hline VERD & 70 & 76 & 66 \\
\hline VEFL & 2 & 0 & 1 \\
\hline VESP & 0 & 0 & 0 \\
\hline VGSW & 0 & 0 & 0 \\
\hline VIRA & 1 & 0 & 0 \\
\hline VIWA & 0 & 1 & 0 \\
\hline WAVI & 0 & 1 & 0 \\
\hline
\end{tabular}

8

23

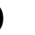

4

0

55

0

0

0

0

0

0 


$\begin{array}{ll}\text { Western Bluebird } & \text { Sialia mexicana } \\ \text { Western Kingbird } & \text { Tyrannus verticalis } \\ \text { Western Meadowlark } & \text { Sturnella neglecta } \\ \text { Western Sandpiper } & \text { Calidris mauri } \\ \text { Western Scrub-Jay } & \text { Aphelocoma californica } \\ \text { Western Tanager } & \text { Piranga ludoviciana } \\ \text { Western Wood-Pewee } & \text { Contopus sordidulus } \\ \text { White-breasted Nuthatch } & \text { Sitta carolinensis } \\ \text { White-crowned Sparrow } & \text { Zonotrichia leucophrys } \\ \text { White-faced Ibis } & \text { Plegadis chihi } \\ \text { White-throated Swift } & \text { Aeronautes saxatalis } \\ \text { White-winged Dove } & \text { Zenaida asiatica } \\ \text { Willet } & \text { Tringa semipalmata } \\ \text { Wilson's Phalarope } & \text { Phalaropus tricolor } \\ \text { Wilson's Snipe } & \text { Gallinago delicata } \\ \text { Wilson's Warbler } & \text { Cardellina pusilla } \\ \text { Yellow Warbler } & \text { Setophaga petechia } \\ \text { Yellow-Breasted Chat } & \text { Ictens }\end{array}$

\begin{tabular}{|c|c|c|c|}
\hline WEBL & 0 & 4 & 0 \\
\hline WEKI & 5 & 3 & 0 \\
\hline WEME & 0 & 0 & 24 \\
\hline WESA & 7 & 0 & 2 \\
\hline WESJ & 0 & 0 & 1 \\
\hline WETA & 0 & 0 & 0 \\
\hline WEWP & 0 & 0 & 1 \\
\hline WBNU & 0 & 0 & 2 \\
\hline WCSP & 32 & 14 & 148 \\
\hline WFIB & 1 & 0 & 124 \\
\hline WTSW & 0 & 0 & 0 \\
\hline WWDO & 23 & 37 & 0 \\
\hline WILL & 0 & 1 & 0 \\
\hline WIPH & 7 & 0 & 0 \\
\hline WISN & 0 & 0 & 5 \\
\hline WIWA & 24 & 12 & 2 \\
\hline YEWA & 34 & 14 & 8 \\
\hline YBCH & 0 & 1 & 0 \\
\hline
\end{tabular}


Yellow-headed Blackbird

Yellow-rumped Warbler

Yellow-throated Warbler

Zone-tailed Hawk
Xanthocephalus xanthocephalus

Setophaga coronata

Setophaga dominica

Buteo albonotatus

$\begin{array}{ccccc}\text { YHBL } & 1 & 0 & 0 & 0 \\ \text { YRWA } & 39 & 19 & 80 & 48 \\ \text { YTWA } & 0 & 0 & 0 & 0 \\ \text { ZTHA } & 0 & 0 & 0 & 0\end{array}$


Appendix D. Diversity profiles (Rényi's index family) of bird communities found at four riparian types (12 sites) in central Arizona, USA, for spring and winter of early $(2001,2002,2004)$ and recent (2011-2013) time frames. Riparian types vary by water permanence and degree of human influence: ephemeral-engineered (EE), ephemeral-natural (EN), perennial-engineered (PE), and perennialnatural (PN). Scale parameter (alpha) displayed along the $\mathrm{x}$-axis range from diversity indices more sensitive to rare species $(0)$ to diversity indices more sensitive to abundant species (Inf), therefore, as you move along alpha, rare species are weighted less. Shannon's entropy and Simpson's dominance index are related to alpha at 1 and 2, respectively (Tóthmérész, 1995).

Spring

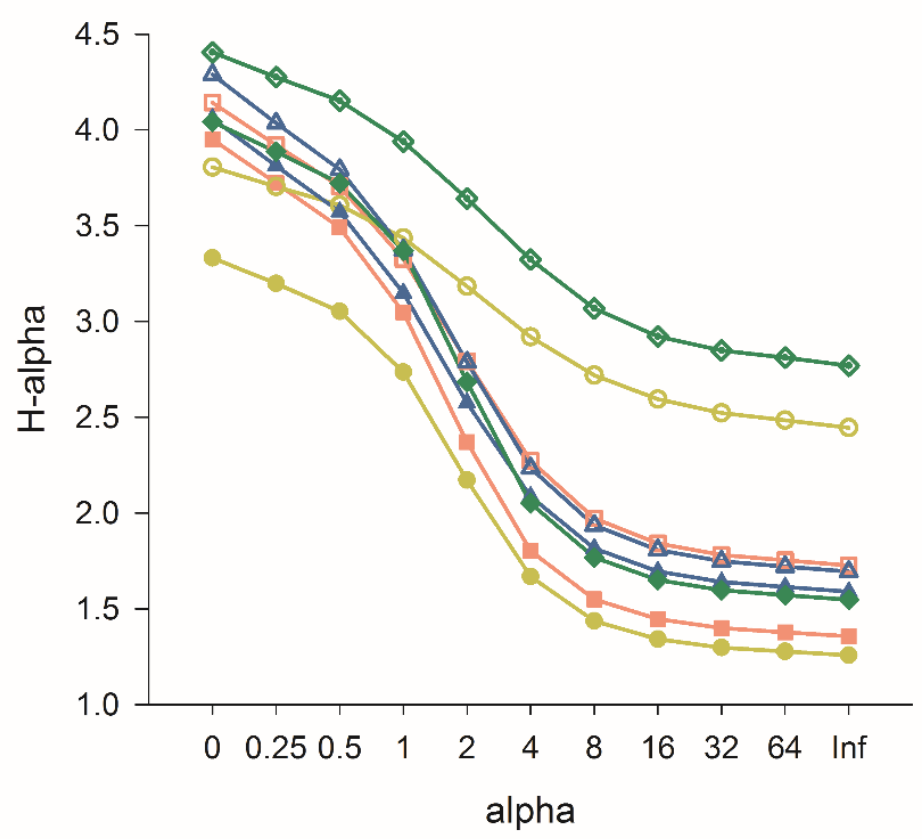

Winter

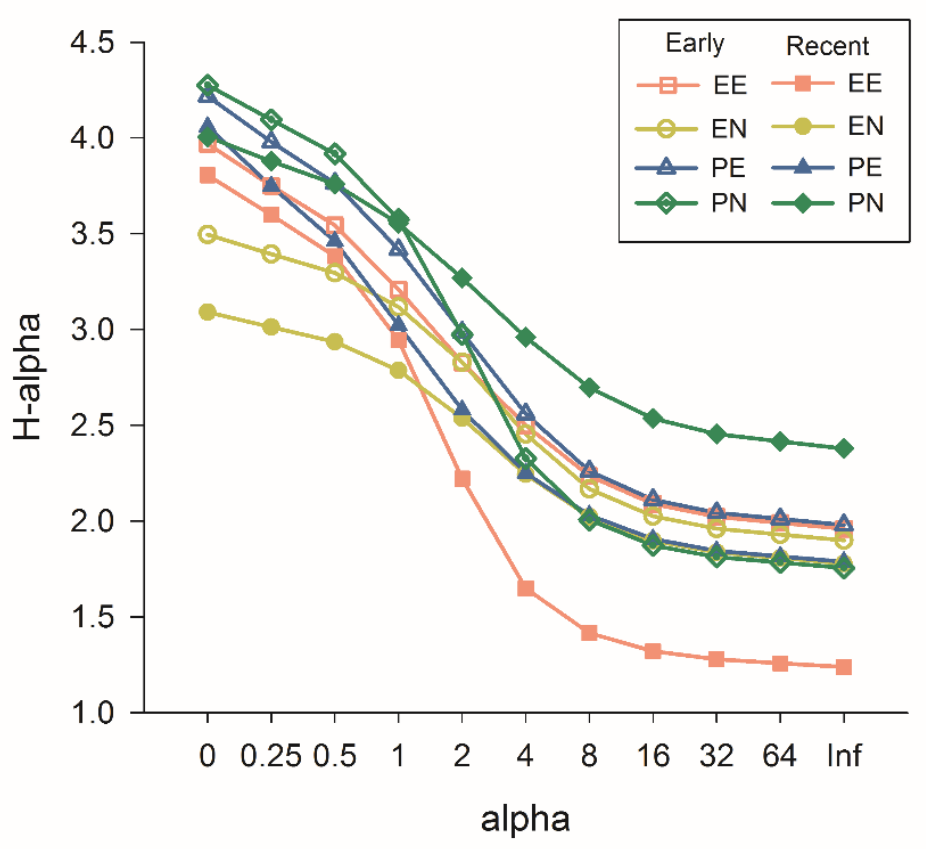


Appendix E. Environmental variables measured at 12 sites across four riparian types in central Arizona, USA. Riparian types vary by water permanence (perennial or ephemeral) and degree of human influence (natural or engineered). Variables were measured during spring of 2013 in the field at the site-level (within 40-m radius around the point) and from 2010 remote-sensed images at the landscape-level (within a $1-\mathrm{km}$ radius around the point).

\begin{tabular}{|c|c|c|c|c|c|}
\hline \multirow[b]{2}{*}{$\begin{array}{l}\text { Site-level } \\
\text { variables }\end{array}$} & \multirow[b]{2}{*}{ Description } & \multicolumn{4}{|c|}{ Riparian types, mean (standard error) } \\
\hline & & $\begin{array}{l}\text { Ephemeral- } \\
\text { engineered }\end{array}$ & $\begin{array}{c}\text { Ephemeral- } \\
\text { natural }\end{array}$ & $\begin{array}{l}\text { Perennial- } \\
\text { engineered }\end{array}$ & $\begin{array}{l}\text { Perennial- } \\
\text { natural }\end{array}$ \\
\hline Marsh_S & percent cover of marsh & $8.2(3.9)$ & $0(0)$ & $11(4)$ & $6(4.6)$ \\
\hline Water_S & percent cover of water & $1.5(0.9)$ & $0(0)$ & $11(4)$ & $26(11.5)$ \\
\hline Imperv_S & percent cover of impervious surface & $8.2(3.9)$ & $7.5(7.5)$ & $6(4.6)$ & $5(5)$ \\
\hline Bare_S & percent cover of bare ground & $61.9(9.7)$ & $50(35)$ & $42.7(19.8)$ & $11(4)$ \\
\hline LowVeg_S & $\begin{array}{l}\text { proportion of vegetation at } 0-0.6 \mathrm{~m} \\
\text { in height from } 10 \text { random points }\end{array}$ & $0.32(0.02)$ & $0.7(0.3)$ & $0.27(0.03)$ & $0.63(0.17)$ \\
\hline MedVeg_S & $\begin{array}{l}\text { proportion of vegetation at } 0.6-1.5 \mathrm{~m} \\
\text { in height from } 10 \text { random points }\end{array}$ & $0.25(0.05)$ & $0.5(0.2)$ & $0.43(0.09)$ & $0.37(0.18)$ \\
\hline HighVeg_S & $\begin{array}{l}\text { proportion of vegetation at }>1.5 \mathrm{~m} \text { in } \\
\text { height from } 10 \text { random points }\end{array}$ & $0.48(0.06)$ & $0.4(0)$ & $0.43(0.07)$ & $0.7(0.06)$ \\
\hline CC_S & $\begin{array}{l}\text { percent canopy cover from } 10 \\
\text { random points }\end{array}$ & $42.4(5.4)$ & $27.5(1.8)$ & $52.9(11.6)$ & $61.6(5.4)$ \\
\hline \multicolumn{6}{|c|}{$\begin{array}{l}\text { Landscape- } \\
\text { level variables }\end{array}$} \\
\hline Imperv_L & percent cover of impervious surface & $40.5(10.4)$ & $2.5(1.7)$ & $21.7(5.6)$ & $1.6(0.4)$ \\
\hline Bare_L & percent cover of bare ground & $47.8(10.9)$ & $68.8(4.8)$ & $46.3(5.1)$ & $50.8(16.6)$ \\
\hline Water_L & percent cover of water & $1.6(1.0)$ & $4.3(2.6)$ & $11.7(4.7)$ & $10.6(4)$ \\
\hline Veg_L & percent cover of vegetation & $10.1(1.4)$ & $24.4(0.6)$ & $15.2(4.3)$ & $32(9.3)$ \\
\hline
\end{tabular}

